\title{
Mesenchymal Stem Cells in Homeostasis and Systemic Diseases: Hypothesis, Evidences, and Therapeutic Opportunities
}

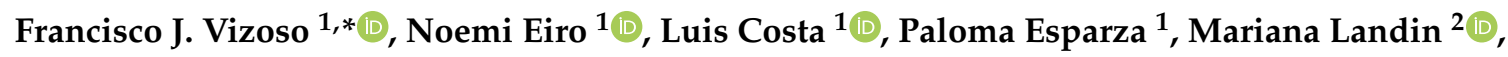 \\ Patricia Diaz-Rodriguez ${ }^{2}{ }^{\mathbb{D}}$, Jose Schneider ${ }^{3}$ and Roman Perez-Fernandez ${ }^{4, *}$ \\ 1 Research Unit, Fundación Hospital de Jove, Avda. Eduardo Castro, 161, 33290 Gijón, Spain \\ 2 Department of Pharmacology, Pharmacy and Pharmaceutical Technology, Faculty of Pharmacy, \\ University of Santiago de Compostela-Campus Vida, 15782 Santiago de Compostela, Spain \\ 3 Department of Obstetrics and Gynecology, Universidad Rey Juan Carlos, Avda. de Atenas s/n, \\ 28922 Alcorcón, Spain \\ 4 Department of Physiology-Center for Research in Molecular Medicine and Chronic Diseases (CIMUS), \\ University of Santiago de Compostela, 15706 Santiago de Compostela, Spain \\ * Correspondence: investigacion@hospitaldejove.com (F.J.V.); roman.perez.fernandez@usc.es (R.P.-F.)
}

Received: 10 July 2019; Accepted: 29 July 2019; Published: 31 July 2019

\begin{abstract}
Mesenchymal stem cells (MSCs) are present in all organs and tissues, playing a well-known function in tissue regeneration. However, there is also evidence indicating a broader role of MSCs in tissue homeostasis. In vivo studies have shown MSC paracrine mechanisms displaying proliferative, immunoregulatory, anti-oxidative, or angiogenic activity. In addition, recent studies also demonstrate that depletion and/or dysfunction of MSCs are associated with several systemic diseases, such as lupus, diabetes, psoriasis, and rheumatoid arthritis, as well as with aging and frailty syndrome. In this review, we hypothesize about the role of MSCs as keepers of tissue homeostasis as well as modulators in a variety of inflammatory and degenerative systemic diseases. This scenario opens the possibility for the use of secretome-derived products from MSCs as new therapeutic agents in order to restore tissue homeostasis, instead of the classical paradigm "one disease, one drug".
\end{abstract}

Keywords: Regenerative medicine; aging diseases; diabetes; lupus; secretome; conditioned medium; extracellular vesicles; exosomes

\section{Introduction}

Many chronic diseases of inflammatory and/or degenerative origin do not currently have satisfactory treatment. The advent of regenerative medicine based on stem cells could provide new promising alternatives. Among the various stem cell types, i.e., hematopoietic, embryonic, induced pluripotent, and mesenchymal, the mesenchymal stem cells (MSCs) are awakening the most extraordinary interest [1] due to the absence of serious adverse effects reported following MSC transplantation, unlike those associated with the allogeneic transplant of hematopoietic stem cells [2].

MSCs were first described in the 1950s by the Russian haematologist A. Friedenstein [3]. They are a heterogeneous group of multipotent cells, morphologically akin to fibroblasts, that form colonies and are capable of differentiate into mesenchymal lineages [4,5]. Although in small amounts, MSCs have been isolated from numerous organs and tissues, such as bone marrow, adipose tissue, umbilical cord, dermis, muscle, synovial membrane, peripheral blood, tonsil, periodontal ligament, dental pulp and uterus, among others [6,7] (some of them summarized in Tables 1 and 2), suggesting a perivascular origin since perivascular cells natively express MSC markers [8]. However, MSCs subtypes differ in their biological features $[9,10]$. 
To refer to mesenchymal-like cells various nomenclatures are used as "mesenchymal stem cells", "mesenchymal stromal cells" and "multipotent stromal cells", but the acronym MSCs is now generally used to identify this class of cells. Because of the initial variation in nomenclature and characterization, the International Society for Cellular Therapy established the minimum criteria required for MSCs definition as follows: (a) plastic-adherent cells when maintained in standard culture conditions; (b) expression of CD105, CD73 and CD90, and lack of expression of CD45, CD34, CD14 or CD19, CD79a or CD11b, and HLA-DR surface molecules, and (c) capacity to differentiate into adipocytes, osteoblasts, and chondroblasts in vitro [11].

Many studies have demonstrated that secretome-derived products from MSCs, such as exosomes and conditioned medium, have therapeutic effects on key pathological processes that are associated with basic homeostatic functions, such as cell differentiation and proliferation, angiogenesis and vasculogenesis, inflammation, and oxidative stress (Tables 1 and 2). 
Table 1. Therapeutic effects of mesenchymal stem cell (MSC)-derived exosomes on disease in vivo models.

\begin{tabular}{|c|c|c|c|c|c|}
\hline Disease & MSC Source & Administration Via & Experimental Model & Therapeutic Effect & Ref \\
\hline \multicolumn{6}{|c|}{ Local administration } \\
\hline \multirow{2}{*}{ Diabetic wound healing } & Gingival & Topical & Diabetic rat & Promotion of healing in diabetic skin defects. & [12] \\
\hline & Synovium & Topical & Diabetic rat & $\begin{array}{l}\text { Stimulation of proliferation of human dermal } \\
\text { fibroblasts and human microvascular endothelial cells. }\end{array}$ & [13] \\
\hline Corneal epithelial wound & Corneal & Local & Mouse & Acceleration of corneal epithelial wound healing. & [14] \\
\hline $\begin{array}{l}\text { Traumatic and degenerative } \\
\text { ocular disease }\end{array}$ & Bone marrow & Intravitreal injection & Rat & $\begin{array}{l}\text { Promotion of retinal ganglion cells and axon } \\
\text { regeneration survival. }\end{array}$ & [15] \\
\hline Autistic-like behaviors & Bone marrow & Intranasal & BTBR mice & $\begin{array}{c}\text { Increase of male to male social interaction and reduce } \\
\text { repetitive behaviors. }\end{array}$ & [16] \\
\hline Liver fibrosis & Umbilical cord & Intra-hepatic & Mouse & $\begin{array}{c}\text { Decrease of surface fibrous capsules and alleviate } \\
\text { hepatic inflammation. }\end{array}$ & [17] \\
\hline \multirow[t]{2}{*}{ Periodontitis } & Adipose-derived & Local Injection & Rat & Increase in newly organized tissue. & [18] \\
\hline & \multicolumn{4}{|c|}{ Systemic administration } & \\
\hline \multirow{4}{*}{ Cutaneous wound healing } & Adipose tissue & Intravenous & Mouse & $\begin{array}{c}\text { Acceleration of cutaneous wound healing and } \\
\text { stimulation of fibroblast migration and } \\
\text { collagen synthesis. }\end{array}$ & [19] \\
\hline & & Subcutaneous injection & & $\begin{array}{l}\text { Promotion of wound healing and angiogenesis. } \\
\text { Promotion of extracellular matrix reconstruction and }\end{array}$ & [20] \\
\hline & Adipose tissue & Intravenous injection & Mouse & $\begin{array}{l}\text { regulation of fibroblast differentiation to mitigate } \\
\text { scar formation. }\end{array}$ & [21] \\
\hline & $\begin{array}{c}\text { Menstrual } \\
\text { blood-derived }\end{array}$ & Intradermic injection & Mouse & $\begin{array}{l}\text { Resolution of inflammation, reepithelization } \\
\text { accelerated by induction of M1-M2 macrophage } \\
\text { polarization and increased neoangiogenesis. }\end{array}$ & [22] \\
\hline Atopic dermatitis & Adipose tissue & $\begin{array}{l}\text { Intravenous and } \\
\text { subcutaneous injection }\end{array}$ & Mouse & $\begin{array}{c}\text { Decrease of clinical score, level of serum IgE, number } \\
\text { of eosinophils in blood and infiltration of mast cells, } \\
\text { CD86+ and CD206+ cells. } \\
\text { Decrease of mRNA expression of } \\
\text { pro-inflammatory cytokines. }\end{array}$ & [23] \\
\hline
\end{tabular}


Table 1. Cont.

\begin{tabular}{|c|c|c|c|c|c|}
\hline Disease & MSC Source & Administration Via & Experimental Model & Therapeutic Effect & Ref \\
\hline Hepatic injury & Umbilical cord & Intravenous & Mouse & Reduction of oxidative stress and apoptosis. & [24] \\
\hline $\begin{array}{l}\text { Endotoxin-induced acute } \\
\text { lung injury }\end{array}$ & Bone marrow & Intravenous & Mouse & $\begin{array}{l}\text { Reduction of white blood cells and neutrophils from } \\
\text { bronchoalveolar lavage fluid (BALF). }\end{array}$ & [25] \\
\hline $\begin{array}{l}\text { Bronchopulmo-nary } \\
\text { dysplasia }\end{array}$ & $\begin{array}{l}\text { Wharton jelly } \\
\text { Bone marrow }\end{array}$ & Intravenous & Mouse & $\begin{array}{l}\text { Amelioration of alveolar simplification, fibrosis and } \\
\text { pulmonary vascular remodelling, reduction of } \\
\text { pro-inflammatory M1, and increase of } \\
\text { anti-inflammatory M2 macrophages. }\end{array}$ & [26] \\
\hline Osteonecrosis & $\begin{array}{l}\text { Synovial } \\
\text { membrane }\end{array}$ & Intramuscular & Rat & $\begin{array}{l}\text { Prevention of osteonecrosis, enhance proliferation and } \\
\text { anti-apoptotic effects. }\end{array}$ & [27] \\
\hline \multicolumn{6}{|c|}{ Local and systemic administration } \\
\hline Pneumonia/E. coli & Bone marrow & $\begin{array}{l}\text { Intratracheal } \\
\text { Intravenous }\end{array}$ & Mouse & $\begin{array}{c}\text { Reduction of lung injury, white blood cells and } \\
\text { neutrophils in BALF. Reduction of E. coli in BALF, } \\
\text { lung and blood. } \\
\text { Increased survival. }\end{array}$ & [28] \\
\hline \multirow[t]{2}{*}{ Lung injury } & Bone marrow & $\begin{array}{l}\text { Intratracheal } \\
\text { Intravenous }\end{array}$ & Mouse & $\begin{array}{l}\text { Reduction of lung injury, white blood cells, } \\
\text { neutrophils, total protein, MIP-1 and E. coli in BALF. } \\
\text { Increase of survival. }\end{array}$ & [29] \\
\hline & Wharton jelly & Intratracheal & Mouse & $\begin{array}{l}\text { Reduction of lung edema, airway resistance, } \\
\text { pulmonary artery pressure, neutrophils in lung, and } \\
\text { inflammatory cytokines in BALF. } \\
\text { Increase of KGF, PGE2 and IL-10 in BALF. }\end{array}$ & [30] \\
\hline \multirow[t]{2}{*}{ Lung fibrosis/Silica } & Bone marrow & Intratracheal & Mouse & $\begin{array}{l}\text { Reduction of calcified nodules size, hydroproline in } \\
\text { lung, and inflammatory cells in BALF. }\end{array}$ & [31] \\
\hline & Bone marrow & Intratravenous & Mouse & $\begin{array}{l}\text { Reduction of lung collagen and white blood cells } \\
\text { in BALF. }\end{array}$ & [32] \\
\hline
\end{tabular}


Table 2. Therapeutic effects of MSC-derived conditioned medium on disease in vivo model.

\begin{tabular}{|c|c|c|c|c|c|}
\hline Disease & MSC Source & Administration Via & Experimental Model & Therapeutic Effect & Ref \\
\hline \multicolumn{6}{|c|}{ Local administration } \\
\hline $\begin{array}{l}\text { Cutaneous wound } \\
\text { healing }\end{array}$ & Bone marrow & Local & $\mathrm{T} 1$ diabetic rats & Acceleration of wound healing. & [33] \\
\hline Keloid & Adipose tissue & Local & Mouse & $\begin{array}{c}\text { Inhibition of proliferation and collagen synthesis of human } \\
\text { keloid-derived fibroblast. } \\
\text { Reduction of inflammation and fibrosis. }\end{array}$ & [34] \\
\hline \multirow{2}{*}{$\begin{array}{l}\text { Dry eye and corneal } \\
\text { epithelial wound }\end{array}$} & \multirow[t]{2}{*}{ Uterine cervix } & \multirow[t]{2}{*}{ Local } & Rat & $\begin{array}{l}\text { Improvement in wound healing of alkali-injured corneas. } \\
\text { Strong bactericidal effect on infected corneal contact lens }\end{array}$ & [35] \\
\hline & & & Rabbit & $\begin{array}{l}\text { Improvement in epithelial regeneration } \\
\text { Reduction of corneal pro-inflammatory cytokines. }\end{array}$ & [36] \\
\hline Uveitis & Uterine cervix & Topical & Mouse & $\begin{array}{c}\text { Reduction of inflammation, and LPS-induced } \\
\text { pro-inflammatory cytokines. } \\
\text { Decrease in leucocytes in aqueous humor and ocular tissues. }\end{array}$ & {$[37$} \\
\hline \multicolumn{6}{|c|}{ Systemic administration } \\
\hline Acute liver failure & Bone marrow & Intravenous & Rat & $\begin{array}{l}\text { Inhibition of liver injury biomarkers release and promotion of } \\
\text { recovery in liver structure. }\end{array}$ & [38] \\
\hline Multiple sclerosis & $\begin{array}{l}\text { Periodontal } \\
\text { ligament }\end{array}$ & Intravenous & Mouse & $\begin{array}{l}\text { Decrease in clinical and histologic score, and modulation of } \\
\text { inflammation, oxidative stress, and apoptotic pathways. }\end{array}$ & [39] \\
\hline Diabetes & Adipose tissue & Intravenous & Mouse & $\begin{array}{c}\text { Reverse mechanical, thermal allodynia and } \\
\text { thermal hyperalgesia. } \\
\text { Restoration of pro/anti-inflammatory cytokine balance. } \\
\text { Prevention of skin innervation loss and re-establishment of } \\
\text { Th1/Th2 balance. } \\
\text { Recovery of kidney morphology. }\end{array}$ & [40] \\
\hline Pneumonia/E. coli & Bone marrow & Intravenous & Rat & Increase in survival. & [41] \\
\hline Acute kidney injury & Bone marrow & Intramuscular & Rat & Amelioration of kidney injury. & [42] \\
\hline Myocardial infarct & Bone marrow & $\begin{array}{l}\text { Intravenous and } \\
\text { intracoronary }\end{array}$ & Porcine & $\begin{array}{l}\text { Reduction of myocardial infarct size. } \\
\text { Improvement of systolic and diastolic cardiac performance. }\end{array}$ & [43] \\
\hline
\end{tabular}


In addition, recent studies have shown the capacity of MSCs to exert antimicrobial effects, indicating an immune function independent of the host's immune system [44]. Therefore, this experimental and clinical evidence strongly suggests the physiological relevance of MSCs in tissue homeostasis. Because of these properties, MSCs are currently being used in Phase I and II clinical trials in several pathologies, including immunological, bone, heart or neurodegenerative disorders [45], and even in phase III clinical trials in graft-versus-host disease (GVHD), Crohn's disease, myocardial infarction and liver cirrhosis [1].

This present review addresses aspects of MSCs, such as mechanisms of intercellular communication, their dysfunction in different physio-pathological processes, their role in homeostasis, and their possible therapeutic use.

\section{MSCs and Its Secretome in Intercellular Communication}

Several studies have demonstrated that intravenously injected MSCs can migrate specifically to the sites of tissue damage, such as those caused by ischemic conditions or inflammation [46]. Even, it has been demonstrated that systemic administration of MSC was more efficient at all-time points for engraftment compared to after local MSC transplantation [47]. In addition, unlike other stem-cell-based therapies, MSCs do not require differentiation into a mature cell type prior to administration and have strong homing capacities in the damaged sites after cell transplantation [48]. However, the molecular mechanism underlying the efficacy of MSCs in promoting engraftment and the functional recovery of injury sites is still unclear [49]. Studies of the potential of MSCs to treat cardiovascular diseases, have shown the ability of MSCs to form new blood vessels by differentiating into endothelial cells in vivo [50,51]. However, other studies have shown poor viability and survival of transplanted cells into the host tissue [52-54] and often less than 1\% of transplanted MSCs are long-term retained within the target tissue $[55,56]$.

This suggests that the beneficial effects of their transplantation are not the result of the cells themselves, but rather are related to their ability to secrete bioactive factors which provide a favorable microenvironment to injured tissues and help limit the damage area and promote regenerative response [57,58]. In fact, MSC-derived products can effectively mimic the therapeutic effects of MSCs in preclinical models. These secreted bioactive factors may generically be termed "secretome or conditioned medium". This biological product includes molecular soluble factors such as cytokines and growth factors, but also membrane-bound vesicles containing biomolecules. As shown in Tables 1-3, some of these factors are involved in homeostatic and therapeutic actions at multiple levels. As it shown in Tables 1 and 2, probably the most plausible scientific evidence of the biological effects of the MCS-secretome derived products are their reported actions after local administration in several experimental in vivo models. Either the whole conditioned medium or the extracellular vesicles (EVs) obtained from different human origin MSC cultures perform extensive therapeutic benefits. EVs are particles made up of phospholipid membranes that contain growth factors, cytokines, lipids, DNA and various forms of RNA. They represent an intercellular communication pathway and play an important role in several cellular mechanisms, such as the exchange of genetic material, the transfer of biologically active molecules, and the defense against viral attack in mammalian cells [59]. Indeed, EVs interact with recipient cells by mechanisms which resemble those involved in viral entry [60]. Although exosomes are secreted by almost all human cell types, protective effects seem specific to MSC-derived exosomes, unlike, for example, fibroblast-derived exosomes [61]. MSCs secretome may contain three different types of EVs: (a) Exosomes (40-150 nm in diameter); (b) microparticles (50-1000 $\mathrm{nm}$ in diameter), and (c) apoptotic bodies (500-2000 $\mathrm{nm}$ in diameter). 
Table 3. Bioactive factors in MSC-derived secretome.

\begin{tabular}{ccc}
\hline Bioactive Effects & Factors & Ref \\
\hline Proliferation/Regeneration & FGFs, HGF, IGF-1, EGF, PDGF, VEGF, TIMP-1, & TIMP-2, UPAR \\
\hline Angiogenesis & FGFs, HGF, IGF-1, IL-6, MCP-1, PDGF, VEGF & {$[35,62,64]$} \\
\hline Anti-apoptosis & FGF, IL-6, IGF-1, GM-CSF, HGF & {$[35,62-65]$} \\
\hline Anti-fibrosis & FGFs, HGF, TIMP-1, MMPs & {$[35,62,64,66]$} \\
\hline Chemo-attraction & CCLs, CXCLs, G-CSF, LIF, MCP-1 & {$[35,62,65,67]$} \\
\hline Immuno-modulation & IDO, IL-10, IL-6, LIF, NT-3, PGE-2 & {$[37,62,67,68]$} \\
\hline Anti-tumoral & FLT-3, CXC10/IP10, LAP, Light & {$[69]$} \\
\hline Bactericidal & CXC10/IP10, CXCL8/IL8, CXCL1/GRO-7, & {$[35,62]$} \\
\hline Antifungal & CXCL6/GCP-2, CCL20/MIP-3, CCL5/RANTES & {$[70]$} \\
\hline
\end{tabular}

\section{MSCs Dysfunction in Systemic Diseases and Aging}

The idea of MSC dysfunction in systemic diseases arose from the observation that patients with autoimmune diseases such as systemic lupus erythematosus (SLE), diabetes mellitus (DM), rheumatoid arthritis (RA), and multiple sclerosis entered disease remission when treated with mesenchymal or hematopoietic stem cells after allogenic transplants, but not after autologous transplants. These findings were especially relevant in patients with lymphoma or leukemia and a concomitant autoimmune disease, such as psoriasis [71]. It has been hypothesized that the remission took place due to the "resetting" of immune memory, but it could also be due to the restoration of internal homeostasis by the administration of external well-functioning MSCs.

Several recent studies indicate an altered functioning of MSCs in various systemic diseases, the role of MSCs in their pathogenesis and/or the development of associated comorbidities. These alterations may be acquired. One example is the systemic autoimmune disease RA, characterized by cartilage and bone destruction associated with local production of inflammatory mediators. Some studies have demonstrated that increased local production of TNF $\alpha$ may injure the bone marrow (BM) microenvironment and affect the reserves of BM haematopoietic progenitor cells [72]. Moreover, a significant reduction in MSC expansion through passages has been observed in patients with RA suggesting a defective proliferative capacity [73]. Dysfunction in MSCs from several sources (e.g., bone marrow, adipose tissue, umbilical cord, and dermis) has been associated with a number of diseases (Table 4). Among these diseases, SLE and DM are representative of the possible impact on their systemic pathophysiology of MSC dysfunction.

Table 4. MSC dysfunction in diseases.

\begin{tabular}{|c|c|c|c|}
\hline Disease & MSC Source & MSC Features & Ref \\
\hline \multirow{4}{*}{$\begin{array}{l}\text { Systemic } \\
\text { Lupus } \\
\text { Erythematosus }\end{array}$} & \multirow{4}{*}{ Bone marrow } & $\begin{array}{l}\text { Flattened morphology. } \\
\text { Increased cell senescence and apoptosis. } \\
\text { Impaired potential for differentiation and migration. }\end{array}$ & $\begin{array}{c}{[74-76]} \\
{[77]} \\
{[78]}\end{array}$ \\
\hline & & Increased activation of the $\mathrm{p}^{53 / \mathrm{p} 21}$ pathway. & {$[79,80]$} \\
\hline & & $\begin{array}{l}\text { Increased expression of p16 } 16^{\mathrm{INK} 4 \mathrm{a}} \\
\text { Increased reactive oxygen species. }\end{array}$ & {$[80,81]$} \\
\hline & & $\begin{array}{c}\text { Alteration of expression profiles in genes related to } \\
\text { immune function. }\end{array}$ & {$[74,80,82-84]$} \\
\hline
\end{tabular}


Table 4. Cont.

\begin{tabular}{|c|c|c|c|}
\hline Disease & MSC Source & MSC Features & Ref \\
\hline $\begin{array}{l}\text { Idiopathic } \\
\text { pulmonary fibrosis }\end{array}$ & Bone marrow & $\begin{array}{c}\text { Mitochondrial dysfunction, with accumulation of } \\
\text { DNA damage. } \\
\text { Cell senescence. } \\
\text { Decreased capacity to migrate. } \\
\text { Increased pro-inflammatory responses. }\end{array}$ & [85] \\
\hline $\begin{array}{l}\text { Diabetes } \\
\text { mellitus }\end{array}$ & $\begin{array}{l}\text { Bone marrow and } \\
\text { Adipose tissue }\end{array}$ & $\begin{array}{l}\text { Impaired differentiation and decreased proliferation. } \\
\text { Impaired angiogenesis/vasculogenesis. } \\
\text { Increased pro-inflammatory cytokines. } \\
\text { Greater propensity to differentiate into adipocytes. }\end{array}$ & $\begin{array}{c}{[86-89]} \\
{[90-95]} \\
{[96]} \\
{[97]}\end{array}$ \\
\hline Multiple sclerosis & Umbilical cord & $\begin{array}{c}\text { Increased pro-inflammatory cytokines. } \\
\text { Reduced ex vivo proliferation and clonogenic } \\
\text { potential, premature senescence, and accelerated } \\
\text { shortening of telomere terminal } \\
\text { restriction fragments. } \\
\text { Reduced in vitro neuroprotective potential. } \\
\text { Reduced expression, activity, and secretion of } \\
\text { key antioxidants. } \\
\text { Increased susceptibility to nitrosative stress. }\end{array}$ & $\begin{array}{l}{[98]} \\
{[99]} \\
{[100]} \\
{[101]}\end{array}$ \\
\hline $\begin{array}{l}\text { Rheumatoid } \\
\text { arthritis }\end{array}$ & Bone marrow & $\begin{array}{l}\text { Impaired proliferative potential in association with } \\
\text { premature telomere length loss. }\end{array}$ & [73] \\
\hline Parkinson disease & Bone marrow & $\begin{array}{l}\text { Impaired differentiation, mitochondrial dysfunction } \\
\text { and increased ROS generation and oxidative stress. }\end{array}$ & [102] \\
\hline $\begin{array}{l}\text { Amyotrophic lateral } \\
\text { sclerosis }\end{array}$ & Bone marrow & $\begin{array}{l}\text { Reduced migration. } \\
\text { Alterations in metalloproteases. } \\
\text { Reduced capacity of pluripotency and } \\
\text { trophic factor secretion. }\end{array}$ & $\begin{array}{c}{[103]} \\
{[104]} \\
{[103,105]}\end{array}$ \\
\hline Psoriasis & $\begin{array}{l}\text { MSCs in psoriasis } \\
\text { plaques or from areas } \\
\text { surrounding the } \\
\text { psoriasic eruptions }\end{array}$ & $\begin{array}{l}\text { Increased expression of inflammation and } \\
\text { angiogenesis-related genes. }\end{array}$ & [106-110] \\
\hline $\begin{array}{l}\text { Myelodysplastic } \\
\text { syndromes }\end{array}$ & Bone marrow & $\begin{array}{l}\text { Altered morphology, reduced proliferative potential, } \\
\text { p53 pathway activation, dysregulated miRNA in } \\
\text { extracellular vesicles. }\end{array}$ & [111] \\
\hline
\end{tabular}

SLE is a chronic inflammatory disease that affects all major organs and systems of the body. Inflammation has long been proposed as a cause for accelerated aging. Early studies reported that BMSCs from lupus patients, compared to matched controls, had a flattened morphology, proliferated more slowly, showed increased ROS, had increased expression of $\mathrm{p} 16^{\mathrm{INK} 4 \mathrm{a}}$ and increased activation of the $\mathrm{p}^{53} / \mathrm{p}^{21}$ pathway [74]. In addition, genetic alterations have been shown in SLE which have a direct or indirect role in MSC immune-regulation function [112]. For instance, the OAZ transcription factor is over-expressed in MSCs from SLE patients, which impairs MSC regulation of B cells, leading to anti-nuclear antibody production [113]. Similarly, $\mathrm{p} 16^{\text {ink4a }}$, an inhibitor of cyclin-dependent kinase CDK4 and CDK6, related to senescence of MSCs [114], shows increased expression in MSCs from SLE patients, inhibiting TGF- $\beta$ secretion and contributing to the decrease of Treg cells [81].

$\mathrm{DM}$ is the most common metabolic disease. Over 382 million people ( $8.3 \%$ of the world population) are affected, with an estimated increase to 592 million in the next 20 years [115]. DM leads to many life-threatening complications affecting major organs, such as heart, kidneys, and eyes [116]. It has been reported MSCs to adopt an insulin-secreting phenotype $[117,118]$. In association with DM, this hyperglycaemic state is considered a stressor that leads to a pathological microenvironment and compromises MSC functionality. Four types of MSC anomalies are found in DM: altered pro-inflammatory cytokine secretion, altered cellular differentiation and proliferation, changes in angiogenesis/vasculogenesis, and increased oxidative stress. Firstly, in the diabetic milieu, inflammatory cytokines, such as IL-6, are chronically elevated [119]. Considering that MSCs function is highly regulated by cytokines $[96,98,120]$, this might constitute a relevant aspect of the disease. In fact, changes 
in cytokine interactions can induce altered patterns in the MSC secretome [121], which mediates critical cell signaling and migratory pathways [68]. Secondly, regarding differentiation and proliferation of MSCs, many of the complications that arise in diabetes could be the result of MSC dysfunction [97]. MSCs have also been shown to display an increased tendency to differentiate into adipocytes in diabetic states, which may contribute to the disease burden $[95,97,122]$. In addition, the increased tendency of diabetic MSCs to differentiate into adipocytes is often coupled with reduced differentiation into osteoblasts, which has been suggested as the cause of the increased bone fractures and osteoporosis in diabetic patients $[123,124]$. Thirdly, the delicate balance of factors implicated in angiogenesis is well-known to be altered in the diabetic state [94]. Several studies have reported the impaired angiogenic capacity of MSCs as a result of different alterations, such as decreased expression of major angiogenic genes (e.g., VEGF-A, VEGF-C, angiopoietin 1 and angiopoietin 2) [125] or decreased expression of proteins required for endothelial migration and vascular smooth muscle formation (e.g., VE-cadherin and $\alpha$-SMA) [92]. In addition, one subpopulation of MSCs, specifically associated with an elevated angiogenic and vasculogenic gene profile, is expressed at a lower proportion in type 1 and 2-DM cell populations compared to controls [122]. And fourthly, oxidative stress and autophagy has been related the MSC dysfunction in patients with metabolic syndrome and type 2 DM [126].

With respect to aging, by definition stem cells cannot be fully senescent. Their inability to undergo permanent cell cycle arrest is precisely what defines their ability to divide and repopulate. However, MSC functionality declines with aging. In fact, MSCs in early passages have shown better colony efficiency than in later passages [127], which should be taken into consideration for therapeutic purposes.

Several MSC senescence phenotypes have been recognized, such as an increase in flattened morphology, growth arrest in G1 phase of cell cycle, increased expression of senescence-associated lysosomal $\alpha$-L-fucosidase and senescence-associated $\beta$-galactosidase [128]. In addition, reparative capacity of MSCs may decrease with age [129], and MSCs obtained from aged individuals possess reduced immunomodulatory properties compared to those from younger ones [130]. MSCs from both bone marrow and adipose tissues present reduced capacity to handle oxidative stress with increasing donor age [131]. Oxidative stress leads to hyperactivity of pro-growth pathways, such as insulin/IGF-1 and mTOR, and the subsequent accumulation of toxic aggregates and cellular debris ultimately leading to apoptosis, necrosis, or autophagy [132].

MSC senescence may be involved in the loss of tissue homeostasis, which could lead to organs failure and development of age-related diseases. In this sense, there are MSC alterations associated with their multilineage differentiation, homing, immunomodulatory and wound-healing capacity, oxidative stress regulation and intrinsic changes in telomere shortening [133-136]. Collectively, these aging-related stem cells changes ultimately lead to Frailty Syndrome [137]. Frailty has been clinically defined as "a state of increased vulnerability resulting from aging-associated decline in reserve and function across multiple organ systems, such that the ability to cope with every day or acute stressors is compromised" [138]. This may be because of the full senescence of stem cells, and is considered as stem cell exhaustion. Regenerative medicine has been proposed to offer further therapeutic approaches to improve or reverse frailty signs and symptoms [135]. In fact, deterioration of adult stem cells in the adult phase can become an important player in the onset of several aging diseases, such as the metabolic syndrome [139], diabetes mellitus [140,141], rheumatoid arthritis [73], systemic lupus erythematosus [80] or ageing syndromes [142,143]. These diseases are characterized by the perpetuation of inflammatory states, constant emission of "alarm signals," proliferation, mobilization, and finally an endless sequestration of MSCs into the damaged tissues, probably leading to a decrease in the endogenous pool of MSCs, which are perhaps the most important specialized repairing cells [144]. This could lead to irreversible and premature stem cell exhaustion syndrome (SCES), inhibiting the organism to self-repair and survive. 
Aging-related diseases are highly relevant. According to the 2018 Aging and Health report of the World Health Organization, 2 billion people worldwide (22\% of the population) will be over the age of 60 by the year 2050, which is more than double the rate in 2015 (http://www.who.int/ mediacentre/factsheets/fs404/en/). Therefore, a new era of therapeutics focusing on the restoration of MSC functionality could be promising.

\section{Control of Tissue Homeostasis by MSCs: Hypothesis and Therapeutic Opportunities}

Based on the above, the following scenario regarding tissue homeostasis by MSCs leads us to an interesting hypothesis. A damaged somatic cell might send "alarm signals" indicative of dysfunction in the form of exosomes, for example. These membrane-derived vesicles could then be internalized by "resident sentinel" MSCs and would trigger their proliferation and activation in response to the damage in the somatic cell, leading ultimately to the production of a specialized secretome. This secretome, able to establish an intercellular communication and with regenerative, anti-inflammatory, and other above-described properties, would be decisive in restoring the physiological balance in the damaged cell, and by extension, in the whole organ (Figure 1A). This intercellular communication might involve, among others, the newly discovered microanatomical fluid-filled space within and between tissues [145].

According to this hypothesis, a number of different situations could lead to loss of tissue regulation control: (a) inadequate alarm messages by damaged somatic cells (Figure 1B); (b) inadequate response to those alarm signals by MSCs due to their depletion (Figure 1C); (c) inadequate response to alarm signals by MSCs due to primary or secondary cell dysfunction, induced by alterations in tissue microenvironment (Figure 1D); and (d) inadequate response by somatic cells to the intercellular communication signals coming from MSCs (Figure 1E).

A

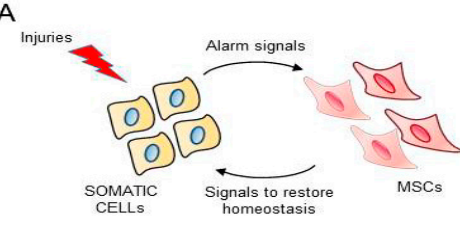

B

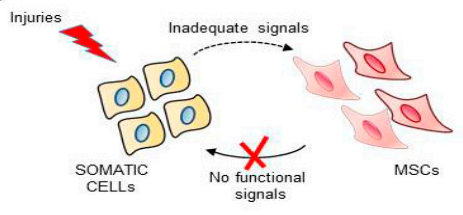

$\mathrm{C}$

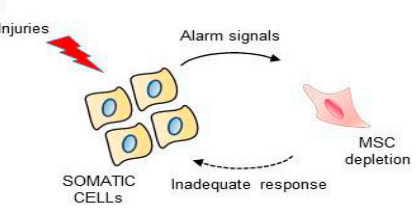

$\mathrm{D}$

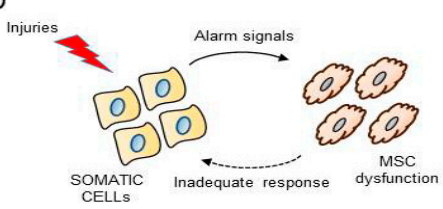

E

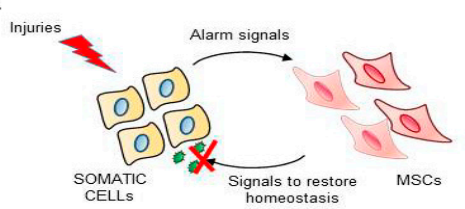

Figure 1. Possible intercellular communication stages between somatic cells and MSCs: (A) damaged somatic cells might send "alarm signals" indicative of dysfunction to "resident sentinel" MSCs which would trigger their proliferation and activation in response to the damage in the somatic cell, leading ultimately to the production of a specialized secretome; $(\mathbf{B})$ inadequate alarm messages by damaged somatic cells; (C) inadequate response to those alarm signals by MSCs due to their depletion; (D) inadequate response to alarm signals by MSCs due to primary or secondary cell dysfunction, induced by alterations in tissue microenvironment; and (E) inadequate response by somatic cells to the intercellular communication signals coming from MSCs.

This new physio-pathological paradigm, together with possible variants, could offer new opportunities in the diagnosis and treatment of homeostasis dysfunction through the identification of quantitative or qualitative alterations corresponding to each of the involved stress signals and the response by MSCs. In a therapeutic setting, the impaired equilibrium could be theoretically restored 
using a specifically designed cocktail of substances aimed at palliating the dysfunction in intercellular communication between damaged somatic cells and MSCs.

For this purpose, secretomes derived from cultured MSCs, including EVs, could be potential candidates, as these secreted and/or derived products have demonstrated their potential for repairing organs and tissues damaged by various degenerative and/or inflammatory disorders (Tables 1 and 2) [6,146]. Furthermore, secretome-derived EVs have therapeutic advantages as they have the ability to protect their cargo from unfavorable environmental conditions, such as changes in $\mathrm{pH}$ or digestive (lytic) enzymes into the bloodstream and damaged tissues.

\section{MSC-Derived Secretome Products as Therapeutic Agents}

The use of MSC-derived secretome products offers key advantages over applications based on stem cells themselves [6]. These advantages include: greater safety, by avoiding issues associated with transplantation of living and proliferative cell populations; better evaluation of MSC-derived secretome regarding dosage and potency, such as conventional pharmaceutical agents; better storage (without presence of potentially toxic cryopreservative agents for a long period and without loss of potency); economical mass-production through tailor-made cell lines under controlled laboratory conditions; and the possibility of being immediately available for acute disease treatment. In addition, MSC-derived secretome could be modified for more effective therapeutic applications.

Nevertheless, several important related aspects must be borne in mind when envisaging further applications of MSCs-derived secretome and its derivates, such as MSC origin, donor condition (age, sex, and health status), as well as several technical and biological aspects related to the development of secretome-derived products

\subsection{Origin of MSCs}

Proteomic comparison of MSC-derived secretomes from different tissue sources have revealed differing profiles and capabilities. For example, MSC-derived secretome from bone marrow, adipose tissue, and dental pulp present different protein composition [147]. It has been also reported that Wharton's jelly-derived MSCs secrete greater amounts of proinflammatory proteins and growth factors, while those derived from adipose tissue have an enhanced angiogenic profile and secrete greater amounts of extracellular matrix proteins and metalloproteases [148]. Thus, the origin of MSCs seems an important aspect related to their possible therapeutic uses. In fact, a MSC population obtained from the human uterine cervical transformation zone [69], displays age-related properties which may affect the regression rate of cervical intraepithelial neoplasia by means of paracrine effects [149]. It has also been recently shown that the conditioned medium from those cells has growth-inhibiting properties against different microorganism species of Candida, a common pathogen of the vaginal medium, to which the cervical transformation zone is in permanent contact [70].

\subsection{Donor Condition}

Theoretically identical MSC populations from different individuals may display different secretome properties, depending on factors including age and health status [150]. Thus, for example, as mentioned above, MSCs obtained from aged individuals possess reduced immunomodulatory properties compared to those from younger subjects, and MSCs from patients affected by several diseases exhibit reduced capabilities $[130,131]$. These points should be considered in the development and application of secretome-derived products, using specific functional tests to ensure homogeneity of action.

\subsection{Bioprocess Development for Secretome-Derived Products}

There are several aspects related to the technical development of secretome-derived products which may influence their potency, such as the specific platform on which cells are grown and culture conditions. 
Commonly, MSCs are grown in 2D monolayers in tissue culture flasks (T-flasks). However, this labor-intensive methodology involves a large number of T-flasks with the risk of flask-to-flask variability and contamination [151]. An alternative for mass production of MSCs is the use of bioreactors in which cells grow homogeneously in 3D suspension [152]. This highly scalable technology allows the cells to form three-dimensional aggregates (spheroids), which are considered to be more biomimetic and capable of increasing the levels of reparative/regenerative, anti-inflammatory and angiogenic factors [153].

Among the culture conditions which may influence the quality of MSC-derived secretome products are: type of media and supplements (e.g., fetal bovine serum, xeno-free, or chemically-defined media), temperature, $\mathrm{pH}$, seeded-cell density, oxygen level, and mechanical, electromagnetic, or biochemical stimuli (e.g., lipopolysaccharide (LPS), TNF- $\alpha$, TNF- $\beta$, INF- $\gamma$ or hydrogen peroxide $-\mathrm{H}_{2} \mathrm{O}_{2}$-) [154]. For example, in response to hypoxia, MSCs increase the production of several angiogenic and anti-apoptotic factors, such as VEGF, IL-6, CCL2, and stanniocalcin-1 (STC-1) [155,156].

These data suggest that it may be possible to adapt secretome-derived products to individual patients (Figure 2). However, it is still necessary to get insight into large-scale production of MSC-derived secretome according to the Good Manufacturing Practices (GMP) guidelines.

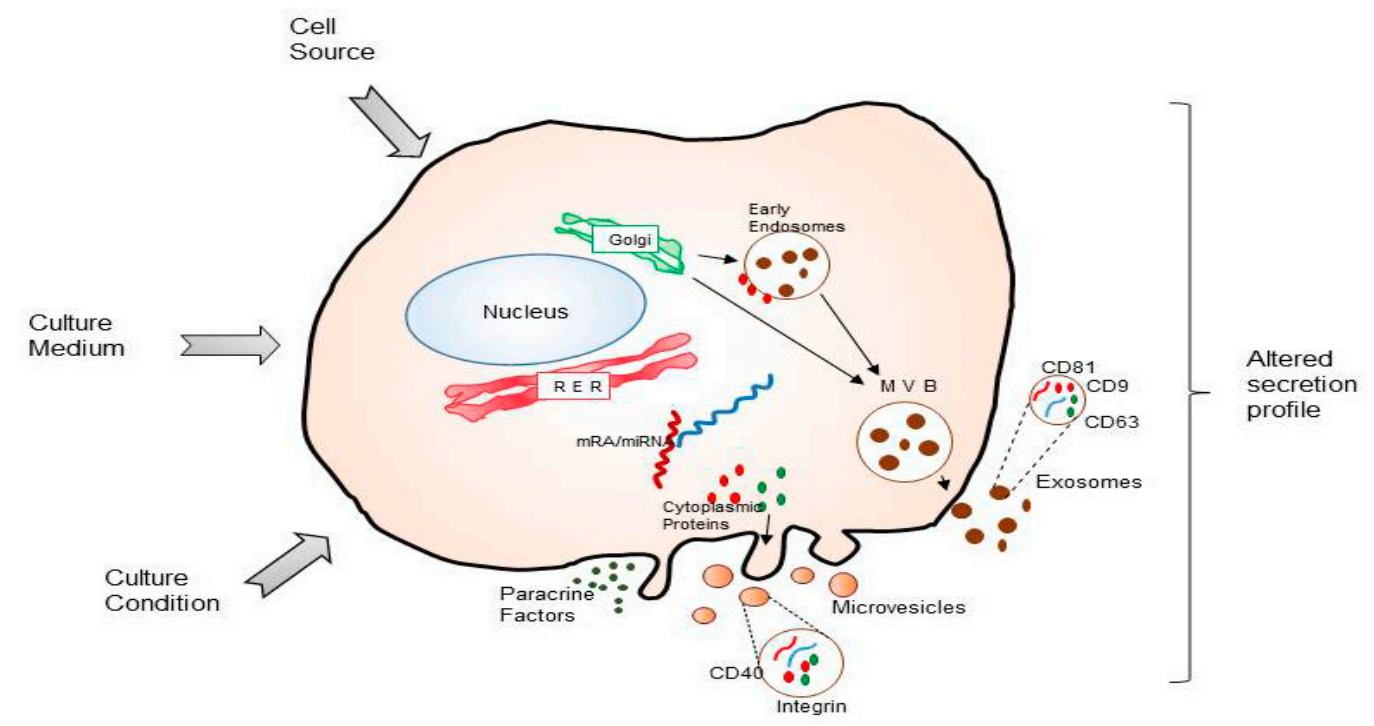

Figure 2. Factors related to bioprocess development (cell source, culture medium and culture conditions) which may influence the quality of MSC secretome-derived products (paracrine factors, microvesicles or exosomes).

Secretome-derived products can be understood as a combination of therapeutic biomacromolecules and vesicles, and thus treated as biopharmaceutics for the development of delivery platforms. The design of delivery systems must guarantee stability, allow easy administration and maximize pharmacological effects. The nature of secretome-based products should allow their loading on micro/nanoparticulated systems of variable composition and structure, which have been widely studied for biomacromolecular therapeutics. This type of carriers can increase macromolecules half-life in vivo, control drug delivery profiles and allow for specific targeting reducing side effects [157-159]. Moreover, the use of other polymeric-based nanostructured drug delivery platforms such as hydrogels has also been widely used for the delivery of biopharmaceuticals. They present similarities to the native extracellular matrix in terms of oxygen and nutrient permeability while showing excellent biocompatibility and porous structure $[160,161]$. Moreover, the use of injectable hydrogels allows for their administration in the target sites with minimal invasiveness permitting local biomacromolecule retention and delivery [162]. 
In summary, there are a wide variety of drug delivery strategies that could be tested for secretome-derived product administration to maintain/increase their potency and efficiency. Secretome-derived products loaded on delivery platforms, could open new possibilities of restoring tissue homeostasis in a controlled manner in time and/or place.

\section{Conclusions and Future Perspectives}

A growing body of evidence suggests the significant role for MSCs in the regulation of tissue homeostasis. These cells are widely distributed throughout the human body and considered the most important type of stem cells involved in tissue regeneration. The positive regenerative, immunoregulatory, proangiogenic, antitumor, and antimicrobial activity of MSCs has also been demonstrated in their secretome-derived products in several in vivo experimental models.

Recently, knowledge has increased regarding the role of morphological and functional alterations of MSCs in several important systemic diseases and the aging process. A paradigm shift could result if the hypothesis is confirmed that alterations in intercellular communication signals between somatic cells and MSCs are key in the occurrence of diseases. This would entail the development of new therapeutic strategies based on the recognition of damaged signals and their restoration, instead of the classical paradigm of "one disease, one drug". This context would require the standardization of secretome-derived products, their manufacture and individual adaptation to each pathological process and patient.

Author Contributions: N.E., L.C., P.E., M.L. and P.D.-R. analyzed the bibliography and prepared the tables and figures. F.J.V., J.S. and R.P.-F. designed the project and wrote the manuscript. All authors reviewed the manuscript.

Funding: This study was supported by Instituto de Salud Carlos III (PI17/02236) to F.J.V., and by Fundación para la Investigación en Células Madre Uterinas (FICEMU) to F.J.V and R.P.-F.

Conflicts of Interest: The authors declare the following competing interests: F.J.V., R.P.-F., and N.E. are co-inventors of a patent ("Human uterine cervical stem cell population and uses thereof") owned by GiStem Research, of which F.J.V, N.E., J.S. and R.P.-F. are shareholders. The founding sponsors had no role in the design of this review, in the collection, analyses, or interpretation of data, in the writing of the manuscript, or in the decision to publish the results.

$\begin{array}{ll}\text { Abbreviations } & \\ \alpha-\Sigma M A & \text { Alpha-smooth muscle actin } \\ \text { BM } & \text { Bone marrow } \\ \text { CCLs } & \text { Chemokine (C-C motif) ligands } \\ \text { CCL2 } & \text { Chemokine (C-C motif) ligand-2 } \\ \text { CCL5 } & \text { Chemokine (C-C motif) ligand-5 } \\ \text { CD } & \text { Cluster of differentiation } \\ \text { CM } & \text { Conditioned medium } \\ \text { CXCLs } & \text { Chemokine (C-X-C motif) ligands } \\ \text { DM } & \text { Diabetes mellitus } \\ \text { DNA } & \text { Deoxyribonucleic acid } \\ \text { EGF } & \text { Epidermal growth factor } \\ \text { Evs } & \text { Extracellular vesicles } \\ \text { Fc } \gamma \text { RIIB } & \text { Inhibitory Fc } \gamma \text { receptor lib } \\ \text { FGFs } & \text { Fibroblast growth factors } \\ \text { FLT-3 ligand } & \text { Fms-related tyrosine kinase 3 ligand } \\ \text { G-CSF } & \text { Granulocyte colony-stimulating factor } \\ \text { GMP } & \text { Good manufacturing Practice } \\ \text { GvHD } & \text { Graft-versus-host disease } \\ \text { H2O2 } & \text { Hydrogen peroxide } \\ \text { HGF } & \text { Hepatocyte growth factor } \\ & \end{array}$




\begin{tabular}{|c|c|}
\hline IDO & Indolamine 2,3-deoxygenase \\
\hline IFN $\gamma$ & Interferon $\gamma$ \\
\hline IGF-1 & Insulin-like growth factor-1 \\
\hline IL & Interleukin \\
\hline IP10 & Interferon-gamma-inducible protein-10 \\
\hline LAP & Latency-associated peptide \\
\hline LIF & Leukemia inhibitory factor \\
\hline LPS & Lipopolysaccharide \\
\hline MCP-1 & Monocyte chemotactic protein- 1 \\
\hline MMP & Matrix metalloproteinase \\
\hline MSC & Mesenchymal stem cell \\
\hline mTOR & mammalian Target of Rapamycin \\
\hline NT-3 & Neurothrofin-3 \\
\hline OAZ & Olfatory-1/early B-cell factor \\
\hline Pbx1 & Pre-B-cell leukemia homeobox 1 \\
\hline PD-1 & Programmed death 1 \\
\hline PDGF & Platelet-derived growth factor \\
\hline PGE-2 & Prostaglandin E2 \\
\hline RA & Rheumatoid arthritis \\
\hline ROS & Reactive oxygen species \\
\hline RNA & Ribonucleic acid \\
\hline SLE & Systemic lupus erythematosus \\
\hline STAT1 & Signal transducer and activator of transcription 1 \\
\hline STC-1 & Stanniocalcin-1 \\
\hline T1DM & Type 1 diabetes mellitus \\
\hline T2DM & Type 2 diabetes mellitus \\
\hline TGF-b & Transforming growth factor-b \\
\hline TIMP & Tissue inhibitor of metalloproteinases \\
\hline TNFa & Tumor necrosis factor alpha \\
\hline uPAR & Urokinase-type plasminogen activator receptor \\
\hline VE-cadherin & vascular endothelial cadherin \\
\hline VEGF & Vascular endothelial growth factor \\
\hline
\end{tabular}

\section{References}

1. Samsonraj, R.M.; Raghunath, M.; Nurcombe, V.; Hui, J.H.; van Wijnen, A.J.; Cool, S.M. Concise Review: Multifaceted Characterization of Human Mesenchymal Stem Cells for Use in Regenerative Medicine. Stem Cells Transl. Med. 2017, 6, 2173-2185. [CrossRef] [PubMed]

2. Zhang, L.B.; He, M. Effect of mesenchymal stromal (stem) cell (MSC) transplantation in asthmatic animal models: A systematic review and meta-analysis. Pulm. Pharmacol. Ther. 2019, 54, 39-52. [CrossRef] [PubMed]

3. Friedenstein, A.J.; Chailakhjan, R.K.; Lalykina, K.S. The development of fibroblast colonies in monolayer cultures of guinea-pig bone marrow and spleen cells. Cell Tissue Kinet. 1970, 3, 393-403. [CrossRef] [PubMed]

4. Afanasyev, B.V.; Elstner, E.E.; Zander, A.R.A.J. Friedenstein, founder of the mesenchymal stem cell concept. Cell. Ther. Transplant. 2009, 1, 35-38. [CrossRef]

5. Uccelli, A.; Moretta, L.; Pistoia, V. Mesenchymal stem cells in health and disease. Nat. Rev. Immunol. 2008, 8, 726-736. [CrossRef] [PubMed]

6. Vizoso, F.J.; Eiro, N.; Cid, S.; Schneider, J.; Perez-Fernandez, R. Mesenchymal Stem Cell Secretome: Toward Cell-Free Therapeutic Strategies in Regenerative Medicine. Int. J. Mol. Sci. 2017, 18, 1852. [CrossRef] [PubMed]

7. Shi, S.; Gronthos, S. Perivascular niche of postnatal mesenchymal stem cells in human bone marrow and dental pulp. J. Bone Miner. Res. 2003, 18, 696-704. [CrossRef] [PubMed]

8. Corselli, M.; Chen, C.W.; Crisan, M.; Lazzari, L.; Peault, B. Perivascular ancestors of adult multipotent stem cells. Arterioscler. Thromb. Vasc. Biol. 2010, 30, 1104-1109. [CrossRef] 
9. Elahi, K.C.; Klein, G.; Avci-Adali, M.; Sievert, K.D.; MacNeil, S.; Aicher, W.K. Human Mesenchymal Stromal Cells from Different Sources Diverge in Their Expression of Cell Surface Proteins and Display Distinct Differentiation Patterns. Stem Cells Int. 2016, 2016, 5646384. [CrossRef]

10. Chen, J.Y.; Mou, X.Z.; Du, X.C.; Xiang, C. Comparative analysis of biological characteristics of adult mesenchymal stem cells with different tissue origins. Asian Pac. J. Trop. Med. 2015, 8, 739-746. [CrossRef]

11. Dominici, M.; Le Blanc, K.; Mueller, I.; Slaper-Cortenbach, I.; Marini, F.; Krause, D.; Deans, R.; Keating, A.; Prockop, D.; Horwitz, E. Minimal criteria for defining multipotent mesenchymal stromal cells. The International Society for Cellular Therapy position statement. Cytotherapy 2006, 8, 315-317. [CrossRef] [PubMed]

12. Shi, Q.; Qian, Z.; Liu, D.; Sun, J.; Wang, X.; Liu, H.; Xu, J.; Guo, X. GMSC-Derived Exosomes Combined with a Chitosan/Silk Hydrogel Sponge Accelerates Wound Healing in a Diabetic Rat Skin Defect Model. Front. Physiol. 2017, 8, 904. [CrossRef] [PubMed]

13. Tao, S.C.; Guo, S.C.; Li, M.; Ke, Q.F.; Guo, Y.P.; Zhang, C.Q. Chitosan Wound Dressings Incorporating Exosomes Derived from MicroRNA-126-Overexpressing Synovium Mesenchymal Stem Cells Provide Sustained Release of Exosomes and Heal Full-Thickness Skin Defects in a Diabetic Rat Model. Stem Cells Transl. Med. 2017, 6, 736-747. [CrossRef] [PubMed]

14. Samaeekia, R.; Rabiee, B.; Putra, I.; Shen, X.; Park, Y.J.; Hematti, P.; Eslani, M.; Djalilian, A.R. Effect of Human Corneal Mesenchymal Stromal Cell-derived Exosomes on Corneal Epithelial Wound HealingCorneal MSC Exosomes Promote Corneal Wound Healing. Investig. Ophthalmol. Vis. Sci. 2018, 59, 5194-5200. [CrossRef] [PubMed]

15. Mead, B.; Tomarev, S. Bone Marrow-Derived Mesenchymal Stem Cells-Derived Exosomes Promote Survival of Retinal Ganglion Cells Through miRNA-Dependent Mechanisms. Stem Cells Transl. Med. 2017, 6, 1273-1285. [CrossRef] [PubMed]

16. Perets, N.; Hertz, S.; London, M.; Offen, D. Intranasal administration of exosomes derived from mesenchymal stem cells ameliorates autistic-like behaviors of BTBR mice. Mol. Autism 2018, 9, 57. [CrossRef] [PubMed]

17. Li, T.; Yan, Y.; Wang, B.; Qian, H.; Zhang, X.; Shen, L.; Wang, M.; Zhou, Y.; Zhu, W.; Li, W.; et al. Exosomes Derived from Human Umbilical Cord Mesenchymal Stem Cells Alleviate Liver Fibrosis. Stem Cells Dev. 2013, 22, 845-854. [CrossRef]

18. Mohammed, E.; Khalil, E.; Sabry, D. Effect of Adipose-Derived Stem Cells and Their Exo as Adjunctive Therapy to Nonsurgical Periodontal Treatment: A Histologic and Histomorphometric Study in Rats. Biomolecules 2018, 8, 167. [CrossRef]

19. Hu, L.; Wang, J.; Zhou, X.; Xiong, Z.; Zhao, J.; Yu, R.; Huang, F.; Zhang, H.; Chen, L. Exosomes derived from human adipose mensenchymal stem cells accelerates cutaneous wound healing via optimizing the characteristics of fibroblasts. Sci. Rep. 2016, 6, 32993. [CrossRef]

20. Zhang, B.; Wu, X.; Zhang, X.; Sun, Y.; Yan, Y.; Shi, H.; Zhu, Y.; Wu, L.; Pan, Z.; Zhu, W.; et al. Human umbilical cord mesenchymal stem cell exosomes enhance angiogenesis through the Wnt $4 / \beta$-catenin pathway. Stem Cells Transl. Med. 2015, 4, 513-522. [CrossRef]

21. Wang, L.; Hu, L.; Zhou, X.; Xiong, Z.; Zhang, C.; Shehada, H.M.A.; Hu, B.; Song, J.; Chen, L. Author Correction: Exosomes secreted by human adipose mesenchymal stem cells promote scarless cutaneous repair by regulating extracellular matrix remodelling. Sci. Rep. 2018, 8, 7066. [CrossRef] [PubMed]

22. Dalirfardouei, R.; Jamialahmadi, K.; Jafarian, A.H.; Mahdipour, E. Promising effects of exosomes isolated from menstrual blood-derived mesenchymal stem cell on wound-healing process in diabetic mouse model. J. Tissue Eng. Regen. Med. 2019, 13, 555-568. [CrossRef] [PubMed]

23. Cho, B.S.; Kim, J.O.; Ha, D.H.; Yi, Y.W. Exosomes derived from human adipose tissue-derived mesenchymal stem cells alleviate atopic dermatitis. Stem Cell Res. Ther. 2018, 9, 187. [CrossRef] [PubMed]

24. Yan, Y.; Jiang, W.; Tan, Y.; Zou, S.; Zhang, H.; Mao, F.; Gong, A.; Qian, H.; Xu, W. hucMSC Exosome-Derived GPX1 Is Required for the Recovery of Hepatic Oxidant Injury. Mol. Ther. 2017, 25, 465-479. [CrossRef] [PubMed]

25. Li, L.; Jin, S.; Zhang, Y. Ischemic preconditioning potentiates the protective effect of mesenchymal stem cells on endotoxin-induced acute lung injury in mice through secretion of exosome. Int. J. Clin. Exp. Med. 2015, 8, 3825-3832. 
26. Willis, G.R.; Fernandez-Gonzalez, A.; Anastas, J.; Vitali, S.H.; Liu, X.; Ericsson, M.; Kwong, A.; Mitsialis, S.A.; Kourembanas, S. Mesenchymal Stromal Cell Exosomes Ameliorate Experimental Bronchopulmonary Dysplasia and Restore Lung Function through Macrophage Immunomodulation. Am. J. Respir. Crit. Care Med. 2018, 197, 104-116. [CrossRef]

27. Guo, S.-C.; Tao, S.-C.; Yin, W.-J.; Qi, X.; Sheng, J.-G.; Zhang, C.-Q. Exosomes from Human Synovial-Derived Mesenchymal Stem Cells Prevent Glucocorticoid-Induced Osteonecrosis of the Femoral Head in the Rat. Int. J. Biol. Sci. 2016, 12, 1262-1272. [CrossRef]

28. Monsel, A.; Zhu, Y.-G.; Gennai, S.; Hao, Q.; Hu, S.; Rouby, J.-J.; Rosenzwajg, M.; Matthay, M.A.; Lee, J.W. Therapeutic Effects of Human Mesenchymal Stem Cell-derived Microvesicles in Severe Pneumonia in Mice. Am. J. Respir. Crit. Care Med. 2015, 192, 324-336. [CrossRef]

29. Zhu, Y.-G.; Feng, X.-M.; Abbott, J.; Fang, X.-H.; Hao, Q.; Monsel, A.; Qu, J.-M.; Matthay, M.A.; Lee, J.W. Human mesenchymal stem cell microvesicles for treatment of Escherichia coli endotoxin-induced acute lung injury in mice. Stem Cells 2014, 32, 116-125. [CrossRef]

30. Stone, M.L.; Zhao, Y.; Robert Smith, J.; Weiss, M.L.; Kron, I.L.; Laubach, V.E.; Sharma, A.K. Mesenchymal stromal cell-derived extracellular vesicles attenuate lung ischemia-reperfusion injury and enhance reconditioning of donor lungs after circulatory death. Respir. Res. 2017, 18, 212. [CrossRef]

31. Phinney, D.G.; Di Giuseppe, M.; Njah, J.; Sala, E.; Shiva, S.; St Croix, C.M.; Stolz, D.B.; Watkins, S.C.; Di, Y.P.; Leikauf, G.D.; et al. Mesenchymal stem cells use extracellular vesicles to outsource mitophagy and shuttle microRNAs. Nat. Commun. 2015, 6, 8472. [CrossRef] [PubMed]

32. Choi, M.; Ban, T.; Rhim, T. Therapeutic use of stem cell transplantation for cell replacement or cytoprotective effect of microvesicle released from mesenchymal stem cell. Mol. Cells 2014, 37, 133-139. [CrossRef] [PubMed]

33. Amini, A.; Pouriran, R.; Abdollahifar, M.-A.; Abbaszadeh, H.A.; Ghoreishi, S.K.; Chien, S.; Bayat, M. Stereological and molecular studies on the combined effects of photobiomodulation and human bone marrow mesenchymal stem cell conditioned medium on wound healing in diabetic rats. J. Photochem. Photobiol. B Biol. 2018, 182, 42-51. [CrossRef] [PubMed]

34. Liu, J.; Ren, J.; Su, L.; Cheng, S.; Zhou, J.; Ye, X.; Dong, Y.; Sun, S.; Qi, F.; Liu, Z.; et al. Human adipose tissue-derived stem cells inhibit the activity of keloid fibroblasts and fibrosis in a keloid model by paracrine signaling. Burns 2018, 44, 370-385. [CrossRef] [PubMed]

35. Bermudez, M.A.; Sendon-Lago, J.; Eiro, N.; Treviño, M.; Gonzalez, F.; Yebra-Pimentel, E.; Giraldez, M.J.; Macia, M.; Lamelas, M.L.; Saa, J.; et al. Corneal Epithelial Wound Healing and Bactericidal Effect of Conditioned Medium from Human Uterine Cervical Stem CellsEffect of CM-hUCESCs on Wound Healing in Dry Eye. Investig. Ophthalmol. Vis. Sci. 2015, 56, 983-992. [CrossRef] [PubMed]

36. Sendon-Lago, J.; Seoane, S.; Martinez-Ordoñez, A.; Eiro, N.; Saa, J.; Vizoso, F.J.; Gonzalez, F.; Perez-Fernandez, R.; Bermudez, M.A. Corneal regeneration by conditioned medium of human uterine cervical stem cells is mediated by TIMP-1 and TIMP-2. Exp. Eye Res. 2019, 180, 110-121. [CrossRef] [PubMed]

37. Bermudez, M.A.; Sendon-Lago, J.; Seoane, S.; Eiro, N.; Gonzalez, F.; Saa, J.; Vizoso, F.; Perez-Fernandez, R. Anti-inflammatory effect of conditioned medium from human uterine cervical stem cells in uveitis. Exp. Eye Res. 2016, 149, 84-92. [CrossRef]

38. Chen, L.; Zhang, J.; Yang, L.; Zhang, G.; Wang, Y.; Zhang, S. The Effects of Conditioned Medium Derived from Mesenchymal Stem Cells Cocultured with Hepatocytes on Damaged Hepatocytes and Acute Liver Failure in Rats. Stem Cells Int. 2018, 2018, 9156560. [CrossRef]

39. Giacoppo, S.; Thangavelu, S.R.; Diomede, F.; Bramanti, P.; Conti, P.; Trubiani, O.; Mazzon, E. Anti-inflammatory effects of hypoxia-preconditioned human periodontal ligament cell secretome in an experimental model of multiple sclerosis: A key role of IL-37. FASEB J. 2017, 31, 5592-5608. [CrossRef]

40. Brini, A.T.; Amodeo, G.; Ferreira, L.M.; Milani, A.; Niada, S.; Moschetti, G.; Franchi, S.; Borsani, E.; Rodella, L.F.; Panerai, A.E.; et al. Therapeutic effect of human adipose-derived stem cells and their secretome in experimental diabetic pain. Sci. Rep. 2017, 7, 9904. [CrossRef]

41. Devaney, J.; Horie, S.; Masterson, C.; Elliman, S.; Barry, F.; O’Brien, T.; Curley, G.F.; O’Toole, D.; Laffey, J.G. Human mesenchymal stromal cells decrease the severity of acute lung injury induced by E. coli in the rat. Thorax 2015, 70, 625-635. [CrossRef] [PubMed] 
42. Salem, M.; Helal, O.; Gabr, H.; El Hady, A.; Ahmed, S. Histological and immunohistochemical study of the role of stem cells, conditioned medium and microvesicles in treatment of experimentally induced acute kidney injury in rats. J. Med. Histol. 2017, 1, 69-83. [CrossRef]

43. Timmers, L.; Lim, S.K.; Arslan, F.; Armstrong, J.S.; Hoefer, I.E.; Doevendans, P.A.; Piek, J.J.; El Oakley, R.M.; Choo, A.; Lee, C.N.; et al. Reduction of myocardial infarct size by human mesenchymal stem cell conditioned medium. Stem Cell Res. 2008, 1, 129-137. [CrossRef] [PubMed]

44. Alcayaga-Miranda, F.; Cuenca, J.; Khoury, M. Antimicrobial Activity of Mesenchymal Stem Cells: Current Status and New Perspectives of Antimicrobial Peptide-Based Therapies. Front. Immunol. 2017, 8, 339. [CrossRef]

45. Nery, A.A.; Nascimento, I.C.; Glaser, T.; Bassaneze, V.; Krieger, J.E.; Ulrich, H. Human mesenchymal stem cells: From immunophenotyping by flow cytometry to clinical applications. Cytom. Part A J. Int. Soc. Anal. Cytol. 2013, 83, 48-61. [CrossRef]

46. Price, M.J.; Chou, C.-C.; Frantzen, M.; Miyamoto, T.; Kar, S.; Lee, S.; Shah, P.K.; Martin, B.J.; Lill, M.; Forrester, J.S.; et al. Intravenous mesenchymal stem cell therapy early after reperfused acute myocardial infarction improves left ventricular function and alters electrophysiologic properties. Int. J. Cardiol. 2006, 111, 231-239. [CrossRef] [PubMed]

47. Ben Menachem-Zidon, O.; Gropp, M.; Ben Shushan, E.; Reubinoff, B.; Shveiky, D. Systemically transplanted mesenchymal stem cells induce vascular-like structure formation in a rat model of vaginal injury. PLoS ONE 2019, 14, e0218081. [CrossRef]

48. Ye, X.; Zhang, C. Effects of Hyperlipidemia and Cardiovascular Diseases on Proliferation, Differentiation and Homing of Mesenchymal Stem Cells. Curr. Stem Cell Res. Ther. 2017, 12, 377-387. [CrossRef]

49. Yun, C.W.; Lee, S.H. Enhancement of Functionality and Therapeutic Efficacy of Cell-Based Therapy Using Mesenchymal Stem Cells for Cardiovascular Disease. Int. J. Mol. Sci. 2019, 20, 982. [CrossRef]

50. Jiang, W.; Ma, A.; Wang, T.; Han, K.; Liu, Y.; Zhang, Y.; Zhao, X.; Dong, A.; Du, Y.; Huang, X.; et al. Intravenous transplantation of mesenchymal stem cells improves cardiac performance after acute myocardial ischemia in female rats. Ransplant Int. 2006, 19, 570-580. [CrossRef]

51. Yue, W.M.; Liu, W.; Bi, Y.W.; He, X.P.; Sun, W.Y.; Pang, X.Y.; Gu, X.H.; Wang, X.P. Mesenchymal stem cells differentiate into an endothelial phenotype, reduce neointimal formation, and enhance endothelial function in a rat vein grafting model. Stem Cells Dev. 2008, 17, 785-794. [CrossRef] [PubMed]

52. Eun, L.Y.; Song, H.; Choi, E.; Lee, T.G.; Moon, D.W.; Hwang, D.; Byun, K.H.; Sul, J.H.; Hwang, K.C. Implanted bone marrow-derived mesenchymal stem cells fail to metabolically stabilize or recover electromechanical function in infarcted hearts. Tissue Cell 2011, 43, 238-245. [CrossRef] [PubMed]

53. McGinley, L.M.; McMahon, J.; Stocca, A.; Duffy, A.; Flynn, A.; O’Toole, D.; O’Brien, T. Mesenchymal stem cell survival in the infarcted heart is enhanced by lentivirus vector-mediated heat shock protein 27 expression. Hum. Gene Ther. 2013, 24, 840-851. [CrossRef] [PubMed]

54. Miao, C.; Lei, M.; Hu, W.; Han, S.; Wang, Q. A brief review: The therapeutic potential of bone marrow mesenchymal stem cells in myocardial infarction. Stem Cell Res. Ther. 2017, 8, 242. [CrossRef] [PubMed]

55. Togel, F.; Hu, Z.; Weiss, K.; Isaac, J.; Lange, C.; Westenfelder, C. Administered mesenchymal stem cells protect against ischemic acute renal failure through differentiation-independent mechanisms. Am. J. Physiol. Ren. Physiol. 2005, 289, F31-F42. [CrossRef] [PubMed]

56. Yeo, R.W.; Lai, R.C.; Zhang, B.; Tan, S.S.; Yin, Y.; Teh, B.J.; Lim, S.K. Mesenchymal stem cell: An efficient mass producer of exosomes for drug delivery. Adv. Drug Deliv. Rev. 2013, 65, 336-341. [CrossRef] [PubMed]

57. Caplan, A.I.; Dennis, J.E. Mesenchymal stem cells as trophic mediators. J. Cell. Biochem. 2006, 98, 1076-1084. [CrossRef] [PubMed]

58. Caplan, A.I. Adult mesenchymal stem cells for tissue engineering versus regenerative medicine. J. Cell. Physiol. 2007, 213, 341-347. [CrossRef] [PubMed]

59. Rosca, A.M.; Rayia, D.M.; Tutuianu, R. Emerging Role of Stem Cells-Derived Exosomes as Valuable Tools for Cardiovascular Therapy. Curr. Stem Cell Res. Ther. 2017, 12, 134-138. [CrossRef]

60. Pitt, J.M.; Kroemer, G.; Zitvogel, L. Extracellular vesicles: Masters of intercellular communication and potential clinical interventions. J. Clin. Investig. 2016, 126, 1139-1143. [CrossRef]

61. Rani, S.; Ryan, A.E.; Griffin, M.D.; Ritter, T. Mesenchymal Stem Cell-derived Extracellular Vesicles: Toward Cell-free Therapeutic Applications. Mol. Ther. J. Am. Soc. Gene Ther. 2015, 23, 812-823. [CrossRef] [PubMed] 
62. Linero, I.; Chaparro, O. Paracrine effect of mesenchymal stem cells derived from human adipose tissue in bone regeneration. PLoS ONE 2014, 9, e107001. [CrossRef] [PubMed]

63. Inukai, T.; Katagiri, W.; Yoshimi, R.; Osugi, M.; Kawai, T.; Hibi, H.; Ueda, M. Novel application of stem cell-derived factors for periodontal regeneration. Biochem. Biophys. Res. Commun. 2013, 430, 763-768. [CrossRef] [PubMed]

64. Wang, M.; Crisostomo, P.R.; Herring, C.; Meldrum, K.K.; Meldrum, D.R. Human progenitor cells from bone marrow or adipose tissue produce VEGF, HGF, and IGF-I in response to TNF by a p38 MAPK-dependent mechanism. Am. J. Physiol. -Regul. Integr. Comp. Physiol. 2006, 291, R880-R884. [CrossRef] [PubMed]

65. Pereira, T.; Ivanova, G.; Caseiro, A.R.; Barbosa, P.; Bártolo, P.J.; Santos, J.D.; Luís, A.L.; Maurício, A.C. MSCs conditioned media and umbilical cord blood plasma metabolomics and composition. PLoS ONE 2014, 9, e113769. [CrossRef] [PubMed]

66. Polacek, M.; Bruun, J.-A.; Elvenes, J.; Figenschau, Y.; Martinez, I. The Secretory Profiles of Cultured Human Articular Chondrocytes and Mesenchymal Stem Cells: Implications for Autologous Cell Transplantation Strategies. Cell Transplant. 2011, 20, 1381-1394. [CrossRef] [PubMed]

67. Liu, C.-H.; Hwang, S.-M. Cytokine interactions in mesenchymal stem cells from cord blood. Cytokine 2005, 32, 270-279. [CrossRef] [PubMed]

68. Kyurkchiev, D.; Bochev, I.; Ivanova-Todorova, E.; Mourdjeva, M.; Oreshkova, T.; Belemezova, K.; Kyurkchiev, S. Secretion of immunoregulatory cytokines by mesenchymal stem cells. World J. Stem Cells 2014, 6, 552-570. [CrossRef]

69. Eiro, N.; Sendon-Lago, J.; Seoane, S.; Bermudez, M.A.; Lamelas, M.L.; Garcia-Caballero, T.; Schneider, J.; Perez-Fernandez, R.; Vizoso, F.J. Potential therapeutic effect of the secretome from human uterine cervical stem cells against both cancer and stromal cells compared with adipose tissue stem cells. Oncotarget 2014, 5, 10692-10708. [CrossRef]

70. Schneider, J.; Mateo, E.; Marcos-Arias, C.; Eiro, N.; Vizoso, F.; Perez-Fernandez, R.; Eraso, E.; Quindos, G. Antifungal Activity of the Human Uterine Cervical Stem Cells Conditioned Medium (hUCESC-CM) Against Candida albicans and Other Medically Relevant Species of Candida. Front. Microbiol. 2018, 9, 2818. [CrossRef]

71. Adkins, D.R.; Abidi, M.H.; Brown, R.A.; Khoury, H.; Goodnough, L.T.; Vij, R.; Westervelt, P.; DiPersio, J.F. Resolution of psoriasis after allogeneic bone marrow transplantation for chronic myelogenous leukemia: Late complications of therapy. Bone Marrow Transpl. 2000, 26, 1239-1241. [CrossRef] [PubMed]

72. Papadaki, H.A.; Kritikos, H.D.; Gemetzi, C.; Koutala, H.; Marsh, J.C.; Boumpas, D.T.; Eliopoulos, G.D. Bone marrow progenitor cell reserve and function and stromal cell function are defective in rheumatoid arthritis: Evidence for a tumor necrosis factor alpha-mediated effect. Blood 2002, 99, 1610-1619. [CrossRef] [PubMed]

73. Kastrinaki, M.C.; Sidiropoulos, P.; Roche, S.; Ringe, J.; Lehmann, S.; Kritikos, H.; Vlahava, V.M.; Delorme, B.; Eliopoulos, G.D.; Jorgensen, C.; et al. Functional, molecular and proteomic characterisation of bone marrow mesenchymal stem cells in rheumatoid arthritis. Ann. Rheum. Dis. 2008, 67, 741-749. [CrossRef] [PubMed]

74. Sun, L.Y.; Zhang, H.Y.; Feng, X.B.; Hou, Y.Y.; Lu, L.W.; Fan, L.M. Abnormality of bone marrow-derived mesenchymal stem cells in patients with systemic lupus erythematosus. Lupus 2007, 16, 121-128. [CrossRef] [PubMed]

75. Nie, Y.; Lau, C.; Lie, A.; Chan, G.; Mok, M. Defective phenotype of mesenchymal stem cells in patients with systemic lupus erythematosus. Lupus 2010, 19, 850-859. [CrossRef] [PubMed]

76. Shi, D.; Li, X.; Chen, H.; Che, N.; Zhou, S.; Lu, Z.; Shi, S.; Sun, L. High level of reactive oxygen species impaired mesenchymal stem cell migration via overpolymerization of F-actin cytoskeleton in systemic lupus erythematosus. Pathol. Biol. 2014, 62, 382-390. [CrossRef] [PubMed]

77. Li, X.; Liu, L.; Meng, D.; Wang, D.; Zhang, J.; Shi, D.; Liu, H.; Xu, H.; Lu, L.; Sun, L. Enhanced apoptosis and senescence of bone-marrow-derived mesenchymal stem cells in patients with systemic lupus erythematosus. Stem Cells Dev. 2012, 21, 2387-2394. [CrossRef]

78. Geng, L.; Li, X.; Feng, X.; Zhang, J.; Wang, D.; Chen, J.; Liu, R.; Chen, H.; Sun, L. Association of TNF- $\alpha$ with impaired migration capacity of mesenchymal stem cells in patients with systemic lupus erythematosus. J. Immunol. Res. 2014, 2014, 169082. [CrossRef]

79. Gu, Z.; Jiang, J.; Tan, W.; Xia, Y.; Cao, H.; Meng, Y.; Da, Z.; Liu, H.; Cheng, C. p53/p21 Pathway involved in mediating cellular senescence of bone marrow-derived mesenchymal stem cells from systemic lupus erythematosus patients. Clin. Dev. Immunol. 2013, 2013, 134243. [CrossRef] 
80. Gao, L.; Bird, A.K.; Meednu, N.; Dauenhauer, K.; Liesveld, J.; Anolik, J.; Looney, R.J. Bone Marrow-Derived Mesenchymal Stem Cells from Patients with Systemic Lupus Erythematosus Have a Senescence-Associated Secretory Phenotype Mediated by a Mitochondrial Antiviral Signaling Protein-Interferon- $\beta$ Feedback Loop. Arthr. Rheumatol. 2017, 69, 1623-1635. [CrossRef]

81. Gu, Z.; Cao, X.; Jiang, J.; Li, L.; Da, Z.; Liu, H.; Cheng, C. Upregulation of p16INK4A promotes cellular senescence of bone marrow-derived mesenchymal stem cells from systemic lupus erythematosus patients. Cell. Signal. 2012, 24, 2307-2314. [CrossRef] [PubMed]

82. Wang, D.; Feng, X.; Lu, L.; Konkel, J.E.; Zhang, H.; Chen, Z.; Li, X.; Gao, X.; Lu, L.; Shi, S.; et al. A CD8 T cell/indoleamine 2,3-dioxygenase axis is required for mesenchymal stem cell suppression of human systemic lupus erythematosus. Arthr. Rheumatol. 2014, 66, 2234-2245. [CrossRef] [PubMed]

83. Tang, Y.; Ma, X.; Zhang, H.; Gu, Z.; Hou, Y.; Gilkeson, G.S.; Lu, L.; Zeng, X.; Sun, L. Gene expression profile reveals abnormalities of multiple signaling pathways in mesenchymal stem cell derived from patients with systemic lupus erythematosus. Clin. Dev. Immunol. 2012, 2012, 826182. [CrossRef] [PubMed]

84. Becker-Merok, A.; Eilertsen, G.Ø.; Nossent, J.C. Levels of Transforming Growth Factor- $\beta$ Are Low in Systemic Lupus Erythematosus Patients with Active Disease. J. Rheumatol. 2010, 37, 2039-2045. [CrossRef] [PubMed]

85. Cárdenes, N.; Álvarez, D.; Sellarés, J.; Peng, Y.; Corey, C.; Wecht, S.; Nouraie, S.M.; Shanker, S.; Sembrat, J.; Bueno, M.; et al. Senescence of bone marrow-derived mesenchymal stem cells from patients with idiopathic pulmonary fibrosis. Stem Cell Res. Ther. 2018, 9, 257. [CrossRef] [PubMed]

86. Deng, X.; Xu, M.; Shen, M.; Cheng, J. Effects of Type 2 Diabetic Serum on Proliferation and Osteogenic Differentiation of Mesenchymal Stem Cells. J. Diabetes Res. 2018, 2018, 5765478. [CrossRef] [PubMed]

87. Moseley, K.F.; Doyle, M.E.; Jan De Beur, S.M. Diabetic serum from older women increases adipogenic differentiation in mesenchymal stem cells. Endocr. Res. 2018, 43, 155-165. [CrossRef]

88. Cramer, C.; Freisinger, E.; Jones, R.K.; Slakey, D.P.; Dupin, C.L.; Newsome, E.R.; Alt, E.U.; Izadpanah, R. Persistent High Glucose Concentrations Alter the Regenerative Potential of Mesenchymal Stem Cells. Stem Cells Dev. 2010, 19, 1875-1884. [CrossRef]

89. Barbagallo, I.; Li Volti, G.; Galvano, F.; Tettamanti, G.; Pluchinotta, F.R.; Bergante, S.; Vanella, L. Diabetic human adipose tissue-derived mesenchymal stem cells fail to differentiate in functional adipocytes. Exp. Biol. Med. 2017, 242, 1079-1085. [CrossRef]

90. Beltramo, E.; Lopatina, T.; Berrone, E.; Mazzeo, A.; Iavello, A.; Camussi, G.; Porta, M. Extracellular vesicles derived from mesenchymal stem cells induce features of diabetic retinopathy In Vitro. Acta Diabetol. 2014, 51, 1055-1064. [CrossRef]

91. Mazzeo, A.; Beltramo, E.; Iavello, A.; Carpanetto, A.; Porta, M. Molecular mechanisms of extracellular vesicle-induced vessel destabilization in diabetic retinopathy. Acta Diabetol. 2015, 52, 1113-1119. [CrossRef]

92. Rezabakhsh, A.; Cheraghi, O.; Nourazarian, A.; Hassanpour, M.; Kazemi, M.; Ghaderi, S.; Faraji, E.; Rahbarghazi, R.; Avci, C.B.; Bagca, B.G.; et al. Type 2 Diabetes Inhibited Human Mesenchymal Stem Cells Angiogenic Response by Over-Activity of the Autophagic Pathway. J. Cell. Biochem. 2017, 118, 1518-1530. [CrossRef] [PubMed]

93. Rezaie, J.; Mehranjani, M.S.; Rahbarghazi, R.; Shariatzadeh, M.A. Angiogenic and Restorative Abilities of Human Mesenchymal Stem Cells Were Reduced Following Treatment with Serum from Diabetes Mellitus Type 2 Patients. J. Cell. Biochem. 2018, 119, 524-535. [CrossRef] [PubMed]

94. Fijany, A.; Sayadi, L.R.; Khoshab, N.; Banyard, D.A.; Shaterian, A.; Alexander, M.; Lakey, J.R.T.; Paydar, K.Z.; Evans, G.R.D.; Widgerow, A.D. Mesenchymal stem cell dysfunction in diabetes. Mol. Biol. Rep. 2019, 46, 1459-1475. [CrossRef] [PubMed]

95. Jumabay, M.; Moon, J.H.; Yeerna, H.; Bostrom, K.I. Effect of Diabetes Mellitus on Adipocyte-Derived Stem Cells in Rat. J. Cell. Physiol. 2015, 230, 2821-2828. [CrossRef] [PubMed]

96. Madhira, S.L.; Challa, S.S.; Chalasani, M.; Nappanveethl, G.; Bhonde, R.R.; Ajumeera, R.; Venkatesan, V. Promise(s) of mesenchymal stem cells as an in vitro model system to depict pre-diabetic/diabetic milieu in WNIN/GR-Ob mutant rats. PLoS ONE 2012, 7, e48061. [CrossRef]

97. Kim, H.; Han, J.W.; Lee, J.Y.; Choi, Y.J.; Sohn, Y.D.; Song, M.; Yoon, Y.S. Diabetic Mesenchymal Stem Cells Are Ineffective for Improving Limb Ischemia Due to Their Impaired Angiogenic Capability. Cell Transpl. 2015, 24, 1571-1584. [CrossRef] 
98. Yuan, Y.; Shi, M.; Li, L.; Liu, J.; Chen, B.; Chen, Y.; An, X.; Liu, S.; Luo, R.; Long, D.; et al. Mesenchymal stem cell-conditioned media ameliorate diabetic endothelial dysfunction by improving mitochondrial bioenergetics via the Sirt1/AMPK/PGC-1alpha pathway. Clin. Sci. 2016, 130, 2181-2198. [CrossRef]

99. Redondo, J.; Sarkar, P.; Kemp, K.; Virgo, P.F.; Pawade, J.; Norton, A.; Emery, D.C.; Guttridge, M.G.; Marks, D.I.; Wilkins, A.; et al. Reduced cellularity of bone marrow in multiple sclerosis with decreased MSC expansion potential and premature ageing in vitro. Mult. Scler. 2018, 24, 919-931. [CrossRef]

100. Sarkar, P.; Redondo, J.; Kemp, K.; Ginty, M.; Wilkins, A.; Scolding, N.J.; Rice, C.M. Reduced neuroprotective potential of the mesenchymal stromal cell secretome with ex vivo expansion, age and progressive multiple sclerosis. Cytotherapy 2018, 20, 21-28. [CrossRef]

101. Redondo, J.; Sarkar, P.; Kemp, K.; Heesom, K.J.; Wilkins, A.; Scolding, N.J.; Rice, C.M. Dysregulation of Mesenchymal Stromal Cell Antioxidant Responses in Progressive Multiple Sclerosis. Stem Cells Transl. Med. 2018, 7, 748-758. [CrossRef] [PubMed]

102. Angelova, P.R.; Barilani, M.; Lovejoy, C.; Dossena, M.; Viganò, M.; Seresini, A.; Piga, D.; Gandhi, S.; Pezzoli, G.; Abramov, A.Y.; et al. Mitochondrial dysfunction in Parkinsonian mesenchymal stem cells impairs differentiation. Redox Biol. 2017, 14, 474-484. [CrossRef] [PubMed]

103. Cho, G.-W.; Noh, M.-Y.; Kim, H.Y.; Koh, S.-H.; Kim, K.-S.; Kim, S.H. Bone Marrow-Derived Stromal Cells from Amyotrophic Lateral Sclerosis Patients Have Diminished Stem Cell Capacity. Stem Cells Dev. 2010, 19, 1035-1042. [CrossRef] [PubMed]

104. Bossolasco, P.; Cova, L.; Calzarossa, C.; Servida, F.; Mencacci, N.E.; Onida, F.; Polli, E.; Lambertenghi Deliliers, G.; Silani, V. Metalloproteinase alterations in the bone marrow of ALS patients. J. Mol. Med. 2010, 88, 553-564. [CrossRef] [PubMed]

105. Koh, S.-H.; Baik, W.; Noh, M.Y.; Cho, G.W.; Kim, H.Y.; Kim, K.S.; Kim, S.H. The functional deficiency of bone marrow mesenchymal stromal cells in ALS patients is proportional to disease progression rate. Exp. Neurol. 2012, 233, 472-480. [CrossRef]

106. Liu, R.F.; Wang, F.; Wang, Q.; Zhao, X.C.; Zhang, K.M. Research Note Mesenchymal stem cells from skin lesions of psoriasis patients promote proliferation and inhibit apoptosis of HaCaT cells. Genet. Mol. Res. GMR 2015, 14, 17758-17767. [CrossRef] [PubMed]

107. Orciani, M.; Campanati, A.; Salvolini, E.; Lucarini, G.; Di Benedetto, G.; Offidani, A.; Di Primio, R. The mesenchymal stem cell profile in psoriasis. Br. J. Dermatol. 2011, 165, 585-592. [CrossRef]

108. Campanati, A.; Orciani, M.; Consales, V.; Lazzarini, R.; Ganzetti, G.; Di Benedetto, G.; Di Primio, R.; Offidani, A. Characterization and profiling of immunomodulatory genes in resident mesenchymal stem cells reflect the Th1-Th17/Th2 imbalance of psoriasis. Arch. Dermatol. Res. 2014, 306, 915-920. [CrossRef]

109. Hou, R.; Yan, H.; Niu, X.; Chang, W.; An, P.; Wang, C.; Yang, Y.; Yan, X.; Li, J.; Liu, R.; et al. Gene expression profile of dermal mesenchymal stem cells from patients with psoriasis. J. Eur. Acad. Dermatol. Venereol. 2014, 28, 1782-1791. [CrossRef]

110. Hou, R.X.; Liu, R.F.; Zhao, X.C.; Jia, Y.R.; An, P.; Hao, Z.P.; Li, J.Q.; Li, X.H.; Yin, G.H.; Zhang, K.M. Increased miR-155-5p expression in dermal mesenchymal stem cells of psoriatic patients: Comparing the microRNA expression profile by microarray. Genet. Mol. Res. GMR 2016, 15. [CrossRef]

111. Mattiucci, D.; Maurizi, G.; Leoni, P.; Poloni, A. Aging-and Senescence-associated Changes of Mesenchymal Stromal Cells in Myelodysplastic Syndromes. Cell Transpl. 2018, 27, 754-764. [CrossRef] [PubMed]

112. Zhu, Y.; Feng, X. Genetic contribution to mesenchymal stem cell dysfunction in systemic lupus erythematosus. Stem Cell Res. Ther. 2018, 9, 149. [CrossRef]

113. Feng, X.; Che, N.; Liu, Y.; Chen, H.; Wang, D.; Li, X.; Chen, W.; Ma, X.; Hua, B.; Gao, X.; et al. Restored immunosuppressive effect of mesenchymal stem cells on B cells after olfactory $1 /$ early B cell factor-associated zinc-finger protein down-regulation in patients with systemic lupus erythematosus. Arthr. Rheumatol. 2014, 66, 3413-3423. [CrossRef] [PubMed]

114. Shibata, K.R.; Aoyama, T.; Shima, Y.; Fukiage, K.; Otsuka, S.; Furu, M.; Kohno, Y.; Ito, K.; Fujibayashi, S.; Neo, M.; et al. Expression of the p16INK4A gene is associated closely with senescence of human mesenchymal stem cells and is potentially silenced by DNA methylation during in vitro expansion. Stem Cells 2007, 25, 2371-2382. [CrossRef] [PubMed]

115. Scully, T. Diabetes in numbers. Nature 2012, 485, S2-S3. [CrossRef] [PubMed]

116. Forbes, J.M.; Cooper, M.E. Mechanisms of diabetic complications. Physiol. Rev. 2013, 93, 137-188. [CrossRef] 
117. Kim, S.J.; Choi, Y.S.; Ko, E.S.; Lim, S.M.; Lee, C.W.; Kim, D.I. Glucose-stimulated insulin secretion of various mesenchymal stem cells after insulin-producing cell differentiation. J. Biosci. Bioeng. 2012, 113, 771-777. [CrossRef]

118. Ho, J.H.; Tseng, T.C.; Ma, W.H.; Ong, W.K.; Chen, Y.F.; Chen, M.H.; Lin, M.W.; Hong, C.Y.; Lee, O.K. Multiple intravenous transplantations of mesenchymal stem cells effectively restore long-term blood glucose homeostasis by hepatic engraftment and $\beta$-cell differentiation in streptozocin-induced diabetic mice. Cell Transpl. 2012, 21, 997-1009. [CrossRef]

119. Van de Vyver, M.; Niesler, C.; Myburgh, K.H.; Ferris, W.F. Delayed wound healing and dysregulation of IL6/STAT3 signalling in MSCs derived from pre-diabetic obese mice. Mol. Cell. Endocrinol. 2016, 426, 1-10. [CrossRef]

120. Khan, M.; Ali, F.; Mohsin, S.; Akhtar, S.; Mehmood, A.; Choudhery, M.S.; Khan, S.N.; Riazuddin, S. Preconditioning diabetic mesenchymal stem cells with myogenic medium increases their ability to repair diabetic heart. Stem Cell Res. Ther. 2013, 4, 58. [CrossRef]

121. Ranganath, S.H.; Levy, O.; Inamdar, M.S.; Karp, J.M. Harnessing the mesenchymal stem cell secretome for the treatment of cardiovascular disease. Cell Stem Cell 2012, 10, 244-258. [CrossRef] [PubMed]

122. Rennert, R.C.; Sorkin, M.; Januszyk, M.; Duscher, D.; Kosaraju, R.; Chung, M.T.; Lennon, J.; Radiya-Dixit, A.; Raghvendra, S.; Maan, Z.N.; et al. Diabetes impairs the angiogenic potential of adipose-derived stem cells by selectively depleting cellular subpopulations. Stem Cell Res. Ther. 2014, 5, 79. [CrossRef] [PubMed]

123. Brown, M.L.; Yukata, K.; Farnsworth, C.W.; Chen, D.G.; Awad, H.; Hilton, M.J.; O'Keefe, R.J.; Xing, L.; Mooney, R.A.; Zuscik, M.J. Delayed fracture healing and increased callus adiposity in a C57BL/6J murine model of obesity-associated type 2 diabetes mellitus. PLOS ONE 2014, 9, e99656. [CrossRef] [PubMed]

124. De Paula, D.R.M.; Capuano, V.; Filho, D.M.; Carneiro, A.; de Oliveira Crema, V.; de Oliveira, L.F.; Rodrigues, A.R.A.; Montano, N.; da Silva, V.J.D. Biological properties of cardiac mesenchymal stem cells in rats with diabetic cardiomyopathy. Life Sci. 2017, 188, 45-52. [CrossRef] [PubMed]

125. Kota, S.K.; Meher, L.K.; Jammula, S.; Kota, S.K.; Krishna, S.V.; Modi, K.D. Aberrant angiogenesis: The gateway to diabetic complications. Indian J. Endocrinol. Metab. 2012, 16, 918-930. [CrossRef] [PubMed]

126. Kornicka, K.; Houston, J.; Marycz, K. Dysfunction of Mesenchymal Stem Cells Isolated from Metabolic Syndrome and Type 2 Diabetic Patients as Result of Oxidative Stress and Autophagy may Limit Their Potential Therapeutic Use. Stem Cell Rev. 2018, 14, 337-345. [CrossRef]

127. Digirolamo, C.M.; Stokes, D.; Colter, D.; Phinney, D.G.; Class, R.; Prockop, D.J. Propagation and senescence of human marrow stromal cells in culture: A simple colony-forming assay identifies samples with the greatest potential to propagate and differentiate. Br. J. Haematol. 1999, 107, 275-281. [CrossRef]

128. Campisi, J.; d'Adda di Fagagna, F. Cellular senescence: When bad things happen to good cells. Nat. Rev. Mol. Cell Biol. 2007, 8, 729-740. [CrossRef]

129. Alvarez, D.; Levine, M.; Rojas, M. Regenerative medicine in the treatment of idiopathic pulmonary fibrosis: Current position. Stem Cells Cloning Adv. Appl. 2015, 8, 61-65. [CrossRef]

130. Wu, L.W.; Wang, Y.L.; Christensen, J.M.; Khalifian, S.; Schneeberger, S.; Raimondi, G.; Cooney, D.S.; Lee, W.P.; Brandacher, G. Donor age negatively affects the immunoregulatory properties of both adipose and bone marrow derived mesenchymal stem cells. Transp. Immunol. 2014, 30, 122-127. [CrossRef]

131. Kizilay Mancini, O.; Shum-Tim, D.; Stochaj, U.; Correa, J.A.; Colmegna, I. Age, atherosclerosis and type 2 diabetes reduce human mesenchymal stromal cell-mediated T-cell suppression. Stem Cell Res. Ther. 2015, 6, 140. [CrossRef] [PubMed]

132. Haines, D.D.; Juhasz, B.; Tosaki, A. Management of multicellular senescence and oxidative stress. J. Cell. Mol. Med. 2013, 17, 936-957. [CrossRef] [PubMed]

133. Jones, D.L.; Rando, T.A. Emerging models and paradigms for stem cell ageing. Nat. Cell Biol. 2011, 13, 506-512. [CrossRef] [PubMed]

134. Yu, K.R.; Kang, K.S. Aging-related genes in mesenchymal stem cells: A mini-review. Gerontology 2013, 59, 557-563. [CrossRef] [PubMed]

135. Raggi, C.; Berardi, A.C. Mesenchymal stem cells, aging and regenerative medicine. Musclesligaments Tendons J. 2012, 2, 239-242.

136. Li, Y.; Wu, Q.; Wang, Y.; Li, L.; Bu, H.; Bao, J. Senescence of mesenchymal stem cells (Review). Int. J. Mol. Med. 2017, 39, 775-782. [CrossRef] [PubMed] 
137. Golpanian, S.; DiFede, D.L.; Pujol, M.V.; Lowery, M.H.; Levis-Dusseau, S.; Goldstein, B.J.; Schulman, I.H.; Longsomboon, B.; Wolf, A.; Khan, A.; et al. Rationale and design of the allogeneiC human mesenchymal stem cells (hMSC) in patients with aging fRAilTy via intravenoUS delivery (CRATUS) study: A phase I/II, randomized, blinded and placebo controlled trial to evaluate the safety and potential efficacy of allogeneic human mesenchymal stem cell infusion in patients with aging frailty. Oncotarget 2016, 7, 11899-11912. [CrossRef] [PubMed]

138. Chen, X.; Mao, G.; Leng, S.X. Frailty syndrome: An overview. Clin. Interv. Aging 2014, 9, 433-441. [CrossRef]

139. Mansilla, E.; Diaz Aquino, V.; Zambon, D.; Marin, G.H.; Martire, K.; Roque, G.; Ichim, T.; Riordan, N.H.; Patel, A.; Sturla, F.; et al. Could metabolic syndrome, lipodystrophy, and aging be mesenchymal stem cell exhaustion syndromes? Stem Cells Int. 2011, 2011, 943216. [CrossRef] [PubMed]

140. Leslie, W.D.; Rubin, M.R.; Schwartz, A.V.; Kanis, J.A. Type 2 diabetes and bone. J. Bone Miner. Res. 2012, 27, 2231-2237. [CrossRef] [PubMed]

141. Vasam, G.; Joshi, S.; Thatcher, S.E.; Bartelmez, S.H.; Cassis, L.A.; Jarajapu, Y.P. Reversal of Bone Marrow Mobilopathy and Enhanced Vascular Repair by Angiotensin-(1-7) in Diabetes. Diabetes 2017, 66, 505-518. [CrossRef] [PubMed]

142. Zhang, W.; Li, J.; Suzuki, K.; Qu, J.; Wang, P.; Zhou, J.; Liu, X.; Ren, R.; Xu, X.; Ocampo, A.; et al. Aging stem cells. A Werner syndrome stem cell model unveils heterochromatin alterations as a driver of human aging. Science 2015, 348, 1160-1163. [CrossRef] [PubMed]

143. Liu, G.H.; Barkho, B.Z.; Ruiz, S.; Diep, D.; Qu, J.; Yang, S.L.; Panopoulos, A.D.; Suzuki, K.; Kurian, L.; Walsh, C.; et al. Recapitulation of premature ageing with iPSCs from Hutchinson-Gilford progeria syndrome. Nature 2011, 472, 221-225. [CrossRef] [PubMed]

144. Shi, Y.; Hu, G.; Su, J.; Li, W.; Chen, Q.; Shou, P.; Xu, C.; Chen, X.; Huang, Y.; Zhu, Z.; et al. Mesenchymal stem cells: A new strategy for immunosuppression and tissue repair. Cell Res. 2010, 20, 510-518. [CrossRef] [PubMed]

145. Benias, P.C.; Wells, R.G.; Sackey-Aboagye, B.; Klavan, H.; Reidy, J.; Buonocore, D.; Miranda, M.; Kornacki, S.; Wayne, M.; Carr-Locke, D.L.; et al. Structure and Distribution of an Unrecognized Interstitium in Human Tissues. Sci. Rep. 2018, 8, 4947. [CrossRef] [PubMed]

146. Pawitan, J.A. Prospect of stem cell conditioned medium in regenerative medicine. Biomed Res. Int. 2014, 2014, 965849. [CrossRef] [PubMed]

147. Tachida, Y.; Sakurai, H.; Okutsu, J. Proteomic Comparison of the Secreted Factors of Mesenchymal Stem Cells from Bone Marrow, Adipose Tissue and Dental Pulp. J. Proteom. Bioinform. 2015, 8. [CrossRef]

148. Amable, P.R.; Teixeira, M.V.; Carias, R.B.; Granjeiro, J.M.; Borojevic, R. Protein synthesis and secretion in human mesenchymal cells derived from bone marrow, adipose tissue and Wharton's jelly. Stem Cell Res. Ther. 2014, 5, 53. [CrossRef]

149. Orciani, M.; Caffarini, M.; Lazzarini, R.; Delli Carpini, G.; Tsiroglou, D.; Di Primio, R.; Ciavattini, A. Mesenchymal Stem Cells from Cervix and Age: New Insights into CIN Regression Rate. Oxid. Med. Cell. Longev. 2018, 2018, 1545784. [CrossRef]

150. Mendicino, M.; Bailey, A.M.; Wonnacott, K.; Puri, R.K.; Bauer, S.R. MSC-based product characterization for clinical trials: An FDA perspective. Cell Stem Cell 2014, 14, 141-145. [CrossRef]

151. Panchalingam, K.M.; Jung, S.; Rosenberg, L.; Behie, L.A. Bioprocessing strategies for the large-scale production of human mesenchymal stem cells: A review. Stem Cell Res. Ther. 2015, 6, 225. [CrossRef] [PubMed]

152. Schnitzler, A.C.; Verma, A.; Kehoe, D.E.; Jing, D.; Murrell, J.R.; Der, K.A.; Aysola, M.; Rapiejko, P.J.; Punreddy, S.; Rook, M.S. Bioprocessing of human mesenchymal stem/stromal cells for therapeutic use: Current technologies and challenges. Biochem. Eng. J. 2016, 108, 3-13. [CrossRef]

153. Cesarz, Z.; Tamama, K. Spheroid Culture of Mesenchymal Stem Cells. Stem Cells Int. 2016, $2016,9176357$. [CrossRef] [PubMed]

154. Phelps, J.; Sanati-Nezhad, A.; Ungrin, M.; Duncan, N.A.; Sen, A. Bioprocessing of Mesenchymal Stem Cells and Their Derivatives: Toward Cell-Free Therapeutics. Stem Cells Int. 2018, 2018, 9415367. [CrossRef] [PubMed]

155. Hung, S.C.; Pochampally, R.R.; Chen, S.C.; Hsu, S.C.; Prockop, D.J. Angiogenic effects of human multipotent stromal cell conditioned medium activate the PI3K-Akt pathway in hypoxic endothelial cells to inhibit apoptosis, increase survival, and stimulate angiogenesis. Stem Cells 2007, 25, 2363-2370. [CrossRef] [PubMed] 
156. Block, G.J.; Ohkouchi, S.; Fung, F.; Frenkel, J.; Gregory, C.; Pochampally, R.; DiMattia, G.; Sullivan, D.E.; Prockop, D.J. Multipotent stromal cells are activated to reduce apoptosis in part by upregulation and secretion of stanniocalcin-1. Stem Cells 2009, 27, 670-681. [CrossRef] [PubMed]

157. Liu, H.J.; Xu, P. Smart Mesoporous Silica Nanoparticles for Protein Delivery. Nanomater. 2019, 9, 1-23. [CrossRef] [PubMed]

158. Ding, D.; Zhu, Q. Recent advances of PLGA micro/nanoparticles for the delivery of biomacromolecular therapeutics. Mater. Sci. Eng. Cmater. Biol. Appl. 2018, 92, 1041-1060. [CrossRef] [PubMed]

159. Mukherjee, A.; Waters, A.K.; Kalyan, P.; Achrol, A.S.; Kesari, S.; Yenugonda, V.M. Lipid-polymer hybrid nanoparticles as a next-generation drug delivery platform: State of the art, emerging technologies, and perspectives. Int. J. Nanomed. 2019, 14, 1937-1952. [CrossRef]

160. Garcia Garcia, C.; Kiick, K.L. Methods for producing microstructured hydrogels for targeted applications in biology. Acta Biomater. 2019, 84, 34-48. [CrossRef]

161. Perez-Luna, V.H.; Gonzalez-Reynoso, O. Encapsulation of Biological Agents in Hydrogels for Therapeutic Applications. Gels 2018, 4, 1-30. [CrossRef] [PubMed]

162. Lee, J.H. Injectable hydrogels delivering therapeutic agents for disease treatment and tissue engineering. Biomater. Res. 2018, 22, 27. [CrossRef] [PubMed]

(C) 2019 by the authors. Licensee MDPI, Basel, Switzerland. This article is an open access article distributed under the terms and conditions of the Creative Commons Attribution (CC BY) license (http://creativecommons.org/licenses/by/4.0/). 